\title{
高壓水素添加に依る頁岩油の加工 (1)
}

一一昭和 18 年 6 月 2 日受理—

大陸科學院然料研究室 理學博士 溝 下征

\section{[1]緒言}

タール系或は石油系重質油を觸媒の存在に於て高㱘水素下に處理して品質優秀なる揮發油を 精製せんとする研究は各方面より檢討せられ，既に航空揮發油生產の一方法として工業化しつ ১ある。使用さるべき觸媒の性能站に耐久性江本操作の死命を制するものであり，此の點に關， して注從來多數の研究あるも，最为注自さるべき注觸媒を硫黄とその化合物或は夫れの混合の 形に於て共存せしむる事に依り其の能力を著し、向上せしめ得らる〉事である。原料中に存在 する硫黃注觸媒に對して注有毒にして其の能力を低下せしむるのみをらず，重合作用を促進し てコークスの生成を容易ならしむるとは Taylor, Klever, Krauch 及び Pier(1) 等の述ぶる所

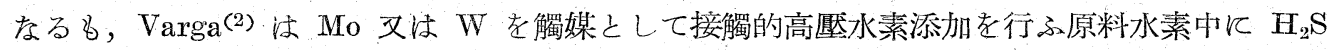
を混在せしむるか或は区應條件の下に $\mathrm{H}_{2} \mathrm{~S}$ を生成するが如を物質を混在せしむれば單に Mo, W を觸媒とせる場合よりも良好なる結果の得らる〉事を認め，又 King 及び Mattewes ${ }^{(3)}$ は Mor r S を共存せしむれば觸媒の性能を向上し得らるb事を, 又 L. Szeszich 及び R. Hupe (4)

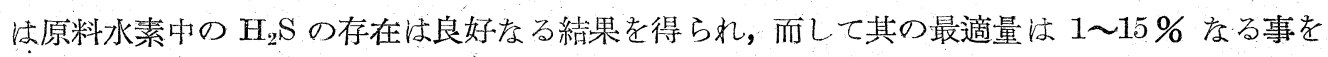
確かめた。著者江頁岩油を適當なる觸媒の存在の下に高壓水素添加法に依り其の品質を向上せ しむる目的を以て先づ頁岩粗油を無觸媒，高厓空素及び高壓水素下に分解して其の分解狀況立 飞生成油の性狀を檢し，炏いで數種觸媒の性能の比較研究を行ひ，Mo 系の觸媒に S を混在せ る 4 成分系觸媒の優秀なる事を確認し，各種最適條件を定め，更に頁岩油各種の油を小型連續 裝置飞依り高厭水素添加せる場合の生成油の性狀の變化につき檢討せる結果につを茲に一括し て述ぶるものである。

[2]試 料 原 油

本研究に使用せる試料原油法撫順製油工場產粗油にして黑褐色を呈し常溫に於て固結し第.1 表の如を性狀を有す。

\section{[3] 實 驗 容 器}

實驗容器法ドイツ製ニッケルクローム內容 $2.8 l$, 常用 $300 \mathrm{~atm}$ 䟎轉式加壓釜， $36 \mathrm{rev} / \mathrm{min}$ 電氣加熱のものである。

\section{[4]實 驗 結 果}

（1）無觸媒，高㗨窒素及び高壓水素下に於ける分解

實驗方法将普通の方法飞從ひ，先づ無觸媒，空素及び水素加壓下に分解せる分解狀況を檢し 生成ガス站に分解油の性狀を檢した。其の結果を第 $2 〜 5$ 表に總括して示す。無觸媒, 窒素加 


\section{第 1 表試 料 原 油}

比重 $\left(40^{\circ} \mathrm{C}\right) 0.872$, 硫黃 $0.59 \%$, 窒素 $0.83 \%$ バラフィン酮ホルデ法 $\left\{\begin{array}{l}\text { 原油に對し } 13.1 \%\left(118.4^{\circ} \mathrm{F}\right) \\ 300^{\circ} \mathrm{O} \text { 以上の溜分に對し } 21.3 \%\end{array}\right.$

分溜試 驗

\begin{tabular}{|c|c|c|c|c|c|}
\hline $\begin{array}{c}\text { 分溜溫度 } \\
{ }^{\left({ }^{\circ} \mathrm{C}\right)}\end{array}$ & $\begin{array}{l}\text { 溜出油量 } \\
\text { (vol\%) }\end{array}$ & $\begin{array}{c}90 \% \mathrm{H}_{2} \mathrm{SO}_{4} \mathrm{~K} \\
\text { よる損失\% }\end{array}$ & $\begin{array}{c}14 \% \mathrm{NaOH} \\
\text { よる損失\% }\end{array}$ & $d_{4^{\circ}}^{25^{\circ}}$ & $n_{D}^{255^{\circ}}$ \\
\hline$\sim 180$ & trace & & & & \\
\hline $180 \sim 200$ & " & & & & \\
\hline $200 \sim 225$ & 1.7 & 26.0 & 13.0 & 0.8420 & 1.4551 \\
\hline $225 \sim 250$ & 4.7 & 30.0 & 9.8 & 0.8453 & 1.4602 \\
\hline $250 \sim 275$ & 6.6 & 33.2 & 8.6 & 0.8532 & 1.4659 \\
\hline $275 \sim 300$ & 9.2 & 38.2 & 9.2 & 0.8619 & 1.4719 \\
\hline $300 \sim$ & 61.4 & & & & \\
\hline 損失及殘椬 & 16.4 & & & & \\
\hline
\end{tabular}

\section{第 2 表后僬條件站飞結果}

\begin{tabular}{|c|c|c|c|c|c|c|c|c|c|c|c|c|}
\hline 貝者 & 番號 & $\begin{array}{l}\text { 使用 } \\
\text { ガス }\end{array}$ & $\begin{array}{l}\text { 初 崕 } \\
\text { (室溫) }\end{array}$ & $\begin{array}{l}\text { 終 厣 } \\
\text { (室溫) }\end{array}$ & $\begin{array}{l}\text { 㙞厢 } \\
\text { (atm) }\end{array}$ & $\begin{array}{l}\text { 堿䵇 } \\
\left(0^{\circ} \mathrm{C}\right)\end{array}$ & $\begin{array}{l}\text { 片ス筧 } \\
\text { 加量 }(l)\end{array}$ & $\begin{array}{l}\text { 水素消 } \\
\text { 費 量 } \\
\text { (mol) }\end{array}$ & $\begin{array}{l}\text { 處理 } \\
\text { 泼慶 } \\
\left({ }^{\circ} \mathrm{C}\right)\end{array}$ & $\begin{array}{l}\text { 甝理 } \\
\text { 時間 } \\
\text { (min) }\end{array}$ & $\begin{array}{c}\text { 最高 } \\
\text { (atm) } \\
(\mathrm{atm})\end{array}$ & $\begin{array}{l}\text { 最低 } \\
\text { 壓力 } \\
\text { (atm) }\end{array}$ \\
\hline No. & 1 & $\mathrm{~N}_{2}$ & $80\left(20^{\circ}\right)$ & $83\left(18^{\circ}\right)$ & 3 & - & 11.5 & - & $402 \pm 4$ & 180 & 210 & - \\
\hline " & 2 & " & " & $87\left(19^{\circ}\right)$ & 7 & - & 24.5 & - & $410 \pm 3$ & " & 228 & $\cdots$ \\
\hline " & 3 & " & " & $88\left(17^{\circ}\right)$ & 8 & - & 27.5 & - & $420 \pm 1$ & " & 248 & - \\
\hline " & 4 & " & $" 1$ & $90\left(16^{\circ}\right)$ & 10 & - & 32.5 & - & $430 \pm 3$ & " & 270 & - \\
\hline "! & 5 & $\mathrm{H}_{2}$ & $80\left(17^{\circ}\right)$ & $74\left(17^{\circ}\right)$ & - & 5.7 & - & 1.3 & $4.00 \pm 3$ & 180 & 180 & 174 \\
\hline "I & 6 & "I & $"$ & $71\left(16^{\circ}\right)$ & $\overline{:}$ & 8.3 & - & 1.8 & $410 \pm 2$ & " & 180 & 174 \\
\hline " & 7 & " & "I & $68\left(17^{\circ}\right)$ & - & 11.4 & - & 2.5 & $419 \pm 1$ & " & 184 & 178 \\
\hline " & 8 & " & " & $60\left(16^{\circ}\right)$ & - & 18.7 & - & 3.2 & $431 \pm 3$ & " & 186 & 178 \\
\hline " & 9 & " & " & $53\left(16^{\circ}\right)$ & - & 25.3 & - & 4.1 & $439 \pm 2$ & " & 192 & 185 \\
\hline " & 10 & " & " & $46\left(14^{\circ}\right)$ & - & 31.6 & - & 5.1 & $449 \pm 3$ & " & 194 & 178 \\
\hline
\end{tabular}

\section{第 3 表 生成油 性 狀}

\begin{tabular}{|c|c|c|c|c|c|c|c|c|c|c|c|c|c|c|}
\hline \multirow{3}{*}{$\begin{array}{l}\text { 䁈 } \\
\text { 驗 } \\
\text { 番 }\end{array}$} & \multirow{3}{*}{$\begin{array}{l}\text { 使 } \\
\text { 妿 } \\
\text { ス }\end{array}$} & \multirow{3}{*}{$\begin{array}{l}\text { 遊離 } \\
\text { 炭素 } \\
(\%)\end{array}$} & \multirow{3}{*}{$\begin{array}{l}\text { 包收 } \\
\text { 率 } \\
\left(\begin{array}{c}\text { vol } \\
\%\end{array}\right)\end{array}$} & \multirow{3}{*}{ 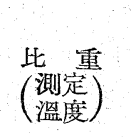 } & \multicolumn{9}{|c|}{ 分 溜 溜 分 (Vol \%) } & \multirow{2}{*}{$\begin{array}{l}\text { 損失 } \\
\text { 文び }\end{array}$} \\
\hline & & & & & & & & & קחק & & & & 300 & \\
\hline & & & & & & & & & & & & & & \\
\hline D. 1 & $\mathrm{~N}_{2}$ & 2.73 & 92.0 & $0.893\left(40^{\circ}\right)$ & 4.2 & 2.8 & 2.5 & 2.2 & 5.1 & 6.0 & 6.3 & 11.2 & 483 & 11.4 \\
\hline 2 & "1 & 5.64 & 87.0 & $0.880\left(30^{\circ}\right)$ & 6.0 & 5.7 & 5.5 & 3.9 & 7.7 & 6.3 & 8.3 & 7.8 & 40.8 & 7.0 \\
\hline 3 & 1 & 11.54 & 79.0 & $0.860\left(25^{\circ}\right)$ & 14.2 & 8.7 & 6.7 & 4.5 & 8.2 & 7.7 & 8.7 & 8.2 & 26.3 & 6.8 \\
\hline 4 & " 1 & $19: 68$ & 70.0 & $0.850\left(20^{\circ}\right)$ & 19.3 & 12.3 & 8.0 & 5.5 & 7.5 & 7.9 & 6.7 & 6.7 & 20.0 & 6.1 \\
\hline 5 & $\mathrm{H}_{2}$ & 0.72 & 95.0 & $0.882\left(40^{\circ}\right)$ & 4.0 & 2.8 & 2.3 & 1.8 & 5.2 & 5.5 & 7.3 & 8.2 & 54.3 & 8.6 \\
\hline 6 & " & 0.86 & 94.0 & $0.878\left(35^{\circ}\right)$ & 4.3 & 3.0 & 2.7 & 2.7 & 5.0 & 6.5 & 9.0 & 8.0 & 52.3 & 6.5 \\
\hline 7 & נI & 0.95 & 90.0 & $0.869\left(35^{\circ}\right)$ & 7.6 & 4.3 & 5.2 & 3.7 & 7.0 & 6.8 & 7.3 & .0 & 44.3 & 6.8 \\
\hline 8. & " & 1.02 & 88.0 & $0.859\left(30^{\circ}\right)$ & 11.7 & 8.0 & 5.5 & 4.3 & 7.8 & 7.3 & 8.0 & 7.7 & 30.7 & 90 \\
\hline 9 & " & 1.81 & 86.0 & $0.846\left(25^{\circ}\right)$ & 15.2 & 11.3 & 7.2 & 5.3 & 7.8 & 7.2 & 7.2 & .3 & 23.3 & 10.2 \\
\hline 10 & & 3.05 & 82.0 & $0.832\left(25^{\circ}\right)$ & 20.7 & 15.0 & 7.7 & 5.5 & 8.7 & 7.2 & 6.0 & 5.3 & 15.3 & 8.6 \\
\hline
\end{tabular}


第 4 表各溜分 の性狀

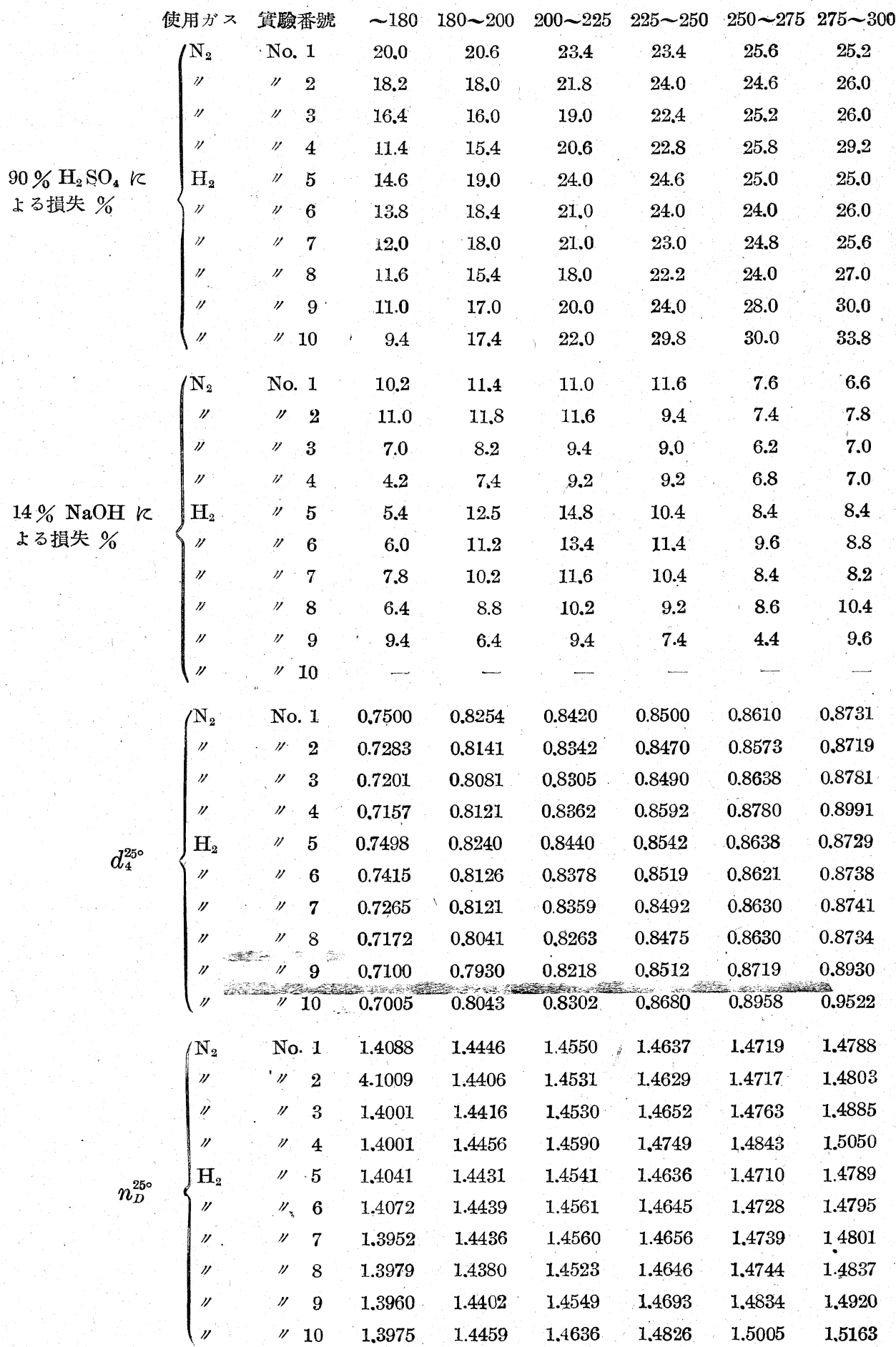


第 5 表生成 ガ 2 成 分

\begin{tabular}{|c|c|c|c|c|c|c|c|c|}
\hline No. 1 & $\mathrm{~N}_{2}$ & 0.1 & 0.1 & 0.1 & 0.4 & 0.0 & 8.2 & 91.1 \\
\hline 2 & Iy & 0.3 & 0.0 & 0.2 & 0.5 & 0.0 & 15.3 & 83.7 \\
\hline 3 & "I & 0.1 & 0.0 & 0.2 & 0.7 & 0.0 & 16.6 & 82.4 \\
\hline 4 & "y & 0.1 & 0.2 & 0.6 & 0.6 & 0.0 & 22.3 & 76.2 \\
\hline 5 & $\mathrm{H}_{2}$ & 0.0 & - & 0.4 & 0.9 & 86.8 & 9.2 & - \\
\hline 6 & " & 0.0 & $\therefore$ & 0.2 & 1.4 & 84.0 & 13,8 & - \\
\hline 7 & " & 0.2 & - & 0.8 & 1.1 & 75.7 & 22.2 & - \\
\hline 8 & "I & 0.0 & - & 0.7 & 1.9 & 74.3 & 25.4 & - \\
\hline 9 & " & 0.1 & - & 0.7 & 1.5 & 67.1 & 33.6 & - \\
\hline " 10 & " & 0.2 & - & 0.7 & 1.4 & 54.5 & 44.9 & - \\
\hline
\end{tabular}

壓下に於ける分解に於ては, 分解油各溜分の $90 \% \mathrm{H}_{2} \mathrm{SO}_{4}$ 飞依る損失 \%は原料油の夫れ飞比 し減少し, $200^{\circ} \mathrm{C}$ 以下の溜分飞於て汢處理溫度の上景と共飞減少すれぞも， $200^{\circ} \mathrm{C}$ 以上の溜分 に於ては反對飞燴加し， $d_{4}^{250}$ 及び $n_{D}^{250}$ は何れも處理溫度の上景と共飞 $200^{\circ} \mathrm{C}$ 以下の溜分飞於

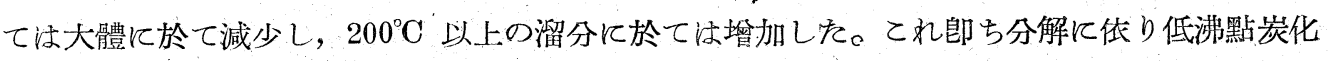
水素を生成すると同時に，オレフィン族炭化水素の如を物質の重合生成物の影響に依るもの之 考へられる。14\% NaOH 飞依る損失\% は處理溫度の上昇と共に減少する。生成ガスの成分は 處理溫度の上昇と共 $\mathrm{C}_{n} \mathrm{H}_{2 n}$ 基の脫却作用盛んとなり, 其の結果生成した $\mathrm{C}_{n} \mathrm{H}_{2 n}$ 基飞水素脫 却に依りて生成せられた發生期の水素が結合して $\mathrm{C}_{n} \mathrm{H}_{2 n+2}$ の量注次第に增加する。次と無觸 媒, 水素加壓下に於ける分解に於ては, 分解に依る水素の消費量注處理溫度の上昇と共飞著し

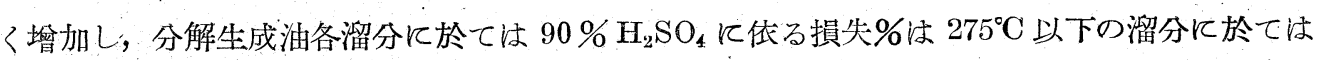
處理溫度 $430^{\circ} \mathrm{C}$ 迄江溫度の上昇と共飞減少するが $440^{\circ} \mathrm{C}, 450^{\circ} \mathrm{C}$ に於て注 $180^{\circ} \mathrm{C}$ 以上の溜分飞 於て既飞增加した。1 $14 \% \mathrm{NaOH}$ 亿依る損失\%杜處理溫度の上开と共飞減少し， $d_{4}^{250}, n_{D}^{25^{\circ}}$ 汢大 體飞於て $\mathrm{H}_{2} \mathrm{SO}_{4}$ 損失\%に比例した。生成ガスの成分注 $\mathrm{C}_{n} \mathrm{H}_{2 n+2}$ の量注處理溫度の上景と共に 增加し, 同一處理溫度に於ける窒素加壓下に於ける場合上りる大である。毁ち無觸媒, 高壓窒 素及び水素の存在の下に分解せしめて其の分解狀海竝に分解油の性狀を檢するに，同一處理溫

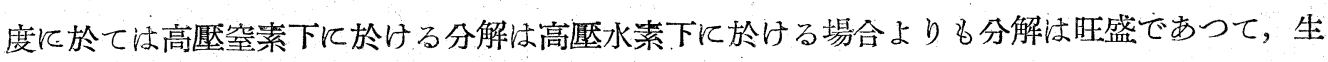
成遊離炭素及び輕質油の量を著しく燴大する。又，觸媒を使用せざる場合と雖も高厴窒素及び 水素上に於て法分解油の不飽和度屿原料油の夫れに比べて減少し，初壓一定なる場合一定の處 理溫度に於て最小なる值を採り，それ以上の溫度に於て注反對に增加する。初壓 $80 \mathrm{~atm}$ とし

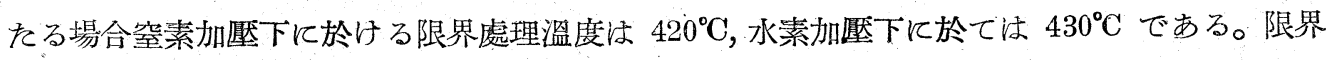
處理溫度以上に於ては分解油各溜分の硫酸損失量, 比重, 屈折率等の著しく增大する事より分 解と同時飞重合作用の旺盛となる事溶易飞想像される。

（2）數種觸媒の水素添加能力の比較

前包々同一試料及び容器を使用し，觸媒の存在の下に高壓水素下で處理し，實驗方法も全く 
同樣であつて，處理後觸媒を濾別した後觸媒に附着した油分はェーテルにて抽出回收し，生成 ガスはアンモニア及び硫化水素を豫め水洗除去したる後分析した。

（i）使用觸媒の調製

（イ） $\mathrm{Fe}$-白土 一定量の硫酸第一鐵の水溶液に 苛性ソーダ溶液を加へて水酸化鐵を 沈澱 せしめ，良く洗滌して母液にアルカリ性を呈せざるに至らしめ，母液を去り濃アンモニア水を 加一良く攪汼しつ」含有せらる」 Fe の量の 3 倍量の酸性白土を加へ，攪汼しつ〉湯煎上に て蒸發乾固したるものを $100^{\circ} \mathrm{C}$ にて 6 時間乾燥したるものである。

（口） $\mathrm{Cu}$-白土 一定量の硫酸第一銅より調製し，其の製法法(イ)と全く同樣である。

（ハ） $\left(\mathrm{NH}_{4}\right)_{6} \cdot \mathrm{MO}_{7} \bullet \mathrm{O}_{24} \cdot 4 \mathrm{H}_{2} \mathrm{O}, \mathrm{MoO}_{3},\left(\mathrm{NH}_{4}\right)_{2} \cdot \mathrm{MoS}_{2}$ 等は何れもメルク製市販品を其の㯖使 用した。

（二） Ni-Mo-S-白土 一定量の硝酸二ッケル水溶液より $10 \% \mathrm{NaOH}$ 溶液に依り水酸化 ニッケルを沈澱せしめ水洗後母液にアルカリ性を呈せざるに至らしめ，母液を去り濃アンモ二 ア水に溶解したるものに金屬 Ni $1 \mathrm{~mol}$ 亿對し $\mathrm{Mo} 1 \mathrm{~mol}$ の比に計算量の $\left(\mathrm{NH}_{4}\right)_{6} \mathrm{MO}_{7} \mathrm{O}_{24} \bullet 4 \mathrm{H}_{2} \mathrm{O}$ の濃アンモ $=ア$ 氷溶液を加へ，加熱し攪汼しつ小硫黄 $4 \mathrm{~mol}$ を添加し，更に Ni そ對し 3 倍 量の酸性白土を添加し，良く攪拌しつ〉加熱してアンモ二ア及び水分を蒸發し，最後に湯煎上 にて蒸發乾固せしめ, $100^{\circ} \mathrm{C}$ にて 6 時間乾燥せしめたるものである。

（ホ）實驗 No. 19, 20，21，23 飞使用した觸媒汒 Ni-Mo-S-白土なる 4 物質系より任意の 1 物質を除き 3 物質系とせるものであつて，其の製法汒(二)之同樣である。

（へ） Fe-Mo-S-白土（二) 亿於ける硝酸ニッケルの代りと硫酸第一鐵を使用せるるので あつて，其の製法法(二)と同樣である。

（ト） $\mathrm{NiO}+\mathrm{MoO}_{3}+\mathrm{S}+$ 白土 $\mathrm{NiO}, \mathrm{MoO}_{3}$ が反應中還元せられて生成する $\mathrm{Ni}, \mathrm{Mo}$ 及び $\mathrm{S}$ ，白土等が原料油飞對する\%を(二)の觸媒と同一ならしむるをめ計算量の $\mathrm{NiO}, \mathrm{MoO}_{3}$, $\mathrm{S}$, 白 土等を良く混合せるものである。

(ii) 實 驗 結 果

上記の方法に依りて調製せる數種の觸媒を使用して實驗せる結果注第 $6 〜 9$ 表に示せる如く である。觸媒の添加量及び原料油飞對する觸媒各成分の重量\%は第 6 表に示す如 $<\mathrm{Fe}, \mathrm{Cu}, \mathrm{Ni}$, Mo 等金屬としての原料油飞對する\%壮甚拮少である。各觸媒につき金屬としての原料油に

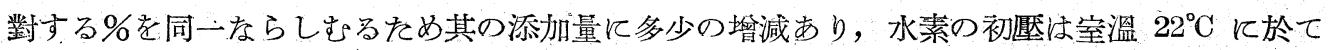
$80 \mathrm{~atm}$ を示すごとく室溫に依り初壓を增減し， $0^{\circ} \mathrm{C}$ 亿換算せる初壓を $74 \mathrm{~atm}$ 亿一定した。減 壓は室溫に於ける終型を $0^{\circ} \mathrm{C}$ 飞換算せるものを初壓より減じをるものであつて, 消費水素のモ

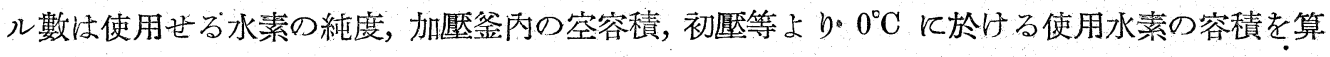
出し, 之より處理油の回收率，終壓，生成ガス中の水素純度等より殘溜ガス中の水素の容積を $0^{\circ} \mathrm{C}$ 亿換算せるものを減じ，mol 數を以て表はしをものである。最高及び最低筀力は觸媒の水 素添加能力に關係を有し，能力優秀なる觸媒を使用せる場合症ど水素の消費多きが故に低下 する。 


\section{第 6 表}

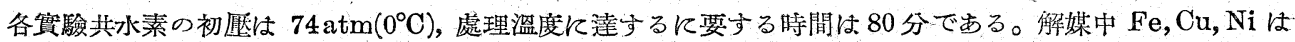
水酸化物，Moはアンモニア監の形に於て存在するが故に“試料飞對する各成分の\%” は之等觸媒が水素氮流 中にて還元せられて金屬 $\mathrm{Fe}, \mathrm{Cu}, \mathrm{Ni}, \mathrm{Mo}$ 々多れる場合の試料に對する\%を示しをるのである。

\begin{tabular}{|c|c|c|c|c|c|c|c|c|c|c|c|c|}
\hline & & & 觸 & 蝶 & & & 水 素 & & 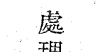 & 處 & 最 & 最 \\
\hline & & 種 類 & $\begin{array}{l}\text { 添加 } \\
\text { 量 } \\
\%\end{array}$ & $\begin{array}{l}\text { 試料に晊 } \\
\text { 各成分。 }\end{array}$ & $\begin{array}{l}\text { 㬗する } \\
0 \%\end{array}$ & $\begin{array}{c}\text { 終厴 } \\
\text { (室温) } \\
\text { atm }\end{array}$ & $\begin{array}{c}\text { 減 厭 } \\
\left(0^{\circ} \mathbf{C}\right) \\
\text { atm }\end{array}$ & $\begin{array}{l}\text { 消費 } \\
\text { 水素 } \\
\mathrm{mol}\end{array}$ & $\begin{array}{l}\text { 涀 } \\
\text { 度 } \\
{ }^{\circ} \mathrm{C}\end{array}$ & $\begin{array}{l}\text { 晧 } \\
\text { min } \\
\text { min }\end{array}$ & $\begin{array}{c}\text { 檿 } \\
\text { atm }\end{array}$ & 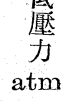 \\
\hline & & Fe-白土 & 10 & $\left\{\begin{array}{l}\mathrm{Fe} \\
\text { 白土 }\end{array}\right.$ & $\begin{array}{l}2.4 \\
6.6\end{array}$ & $53\left(16^{\circ}\right)$ & 23.9 & 2.8 & $423 \pm 1$ & 180 & 187 & \\
\hline & 70 & " & " & " & & $45\left(16^{\circ}\right)$ & 31.5 & 3.8 & $434 \pm 1$ & " & 183 & 154 \\
\hline & 72 & " & " & " & & $47\left(17^{\circ}\right)$ & 29.7 & 3.7 & $451 \pm 1$ & 60 & 189 & 74 \\
\hline & 75 & $\mathrm{Cu}$-白土 & 10 & $\left\{\begin{array}{l}\mathrm{Cu} \\
\text { 白土 }\end{array}\right.$ & $\begin{array}{l}2.4 \\
6.6\end{array}$ & $59\left(15^{\circ}\right)$ & 18.5 & 2.1 & $421 \pm 1$ & 60 & 176 & 170 \\
\hline 1 & 74 & " & " & " & & $54\left(14^{\circ}\right)$ & 22.6 & 2.8 & $433 \pm 2$ & " & 188 & 85 \\
\hline & 73 & $"$ & " & " & & $51\left(18^{\circ}\right)$ & 26.1 & 3.5 & $452 \pm 1$ & " & 189 & \\
\hline & 5 & $\begin{array}{l}\left(\mathrm{NH}_{4}\right)_{6} \mathrm{Mo}_{7} \mathrm{O}_{2} \\
\cdot 4 \mathrm{H}_{2} \mathrm{O}\end{array}$ & $24 \quad 5$ & Mo & 2.6 & $36\left(22^{\circ}\right)$ & 40.7 & 4.7 & $432 \pm 2$ & 180 & 171 & \\
\hline $\mathbb{1}$ & 47 & "I & "I & " & & $47\left(23^{\circ}\right)$ & 30.6 & 3.4 & $435 \pm 2$ & 60 & 176 & 51 \\
\hline$y$ & 7 & $\mathrm{MoO}_{3}$ & 5 & Mo & 3.3 & $41\left(25^{\circ}\right)$ & 36.4 & 4.5 & $434 \pm 1$ & 180 & 171 & \\
\hline " & 45 & " & " & " & & $48\left(22^{\circ}\right)$ & 39.6 & 3.6 & $434 \pm 1$ & 60 & 170 & \\
\hline J & 8 & $\mathrm{MoO}_{3}+\mathrm{S}$ & 8.7 & $\left\{\begin{array}{l}\text { Mo } \\
\mathrm{S}\end{array}\right.$ & $\begin{array}{l}3.3 \\
3.7\end{array}$ & $37\left(22^{\circ}\right)$ & 39.8 & 4.8 & $434 \pm 3$ & 180 & 165 & 36 \\
\hline "I & 46 & " & $"$ & "I. & & $46\left(21^{\circ}\right)$ & 31.3 & 3.6 & $433 \pm 2$ & 60 & 169 & 49 \\
\hline " & 4 & $\left(\mathrm{NH}_{4}\right)_{2} \mathrm{MoS}_{4}$ & 5 & $\mathrm{MoS}_{3}$ & 4.3 & $30\left(24^{\circ}\right)$ & 46.4 & 5.4 & $434 \pm 2$ & 180 & 160 & 27 \\
\hline " & 48 & " & " & " & & $40\left(23^{\circ}\right)$ & 37.1 & 3.9 & $434 \pm 2$ & 60 & 159 & 36 \\
\hline 7 & 12 & $\begin{array}{l}\left(\mathrm{NH}_{4}\right)_{2} \mathrm{MoS}_{4} \\
++\operatorname{ris}^{2}\end{array}$ & 10 & $\left\{\begin{array}{l}\mathrm{MoS}_{\mathrm{g}} \\
\text { 白土 }\end{array}\right.$ & $\begin{array}{l}4.3 \\
4.8\end{array}$ & $35\left(25^{\circ}\right)$ & 41.9 & 4.9 & $435 \pm 2$ & 180 & 168 & 30 \\
\hline "I & 19 & Ni-Mo-白土 & 8.9 & $\left\{\begin{array}{l}\mathrm{Ni} \\
\mathrm{Mo} \\
\text { 白土 }\end{array}\right.$ & $\begin{array}{l}1.1 \\
1.9 \\
3.4\end{array}$ & $40\left(29^{\circ}\right)$ & 37.8 & 4.3 & $433 \pm 2$ & 60 & 163 & 137 \\
\hline " & 80 & " & " & :" & & $43\left(16^{\circ}\right)$ & 33.6 & 3.5 & $423 \pm 2$ & 60 & 165 & 0 \\
\hline I & 20 & Ni-S-白土 & 8.7 & $\left\{\begin{array}{l}\mathrm{Ni} \\
\mathrm{S} \\
\text { 白土 }\end{array}\right.$ & $\begin{array}{l}1.1 \\
2.5 \\
3.4\end{array}$ & $44\left(29^{\circ}\right)$ & 34.2 & 3.8 & $434 \pm 2$ & 60 . & 153 & 137 \\
\hline 1 & 76 & "I & "I & " & & $49\left(15^{\circ}\right)$ & 27.5 & 2.9 & $420 \pm 1$ & 60 & 170 & 150 \\
\hline 7 & 21 & Mo-S-白土 & 8.2 & $\left\{\begin{array}{l}\mathrm{Mo} \\
\mathrm{S} \\
\text { 白土 }\end{array}\right.$ & $\begin{array}{l}1.9 \\
2.5 \\
3.4\end{array}$ & $36\left(26^{\circ}\right)$ & 41.1. & 4.5 & $434 \pm 3$ & 60 & 159 & 136 \\
\hline 1 & 78 & " & " & "I & & $45\left(17^{\circ}\right)$ & 31.6 & 3.4 & $420 \pm 2$ & 60 & 158 & 136 \\
\hline 17 & 23 & $\mathrm{Ni}-\mathrm{Mo}-\mathrm{S}$ & 7.5 & $\left\{\begin{array}{l}\mathrm{Ni} \\
\mathrm{Mo} \\
\mathrm{S}\end{array}\right.$ & $\begin{array}{l}1.1 \\
1.9 \\
2.5\end{array}$ & $29\left(26^{\circ}\right)$ & 47.5 & 5.2 & $435 \pm 1$ & 60 & 144 & 123 \\
\hline " & 79 & " & " & " & & $38\left(19^{\circ}\right)$ & 38.5 & 4.1 & $421 \pm 1$ & 60 & 154 & 28. \\
\hline " & 18 & $\begin{array}{l}\text { Ni-Mo-S-白 } \\
\pm\end{array}$ & 10.9 & $\left\{\begin{array}{l}\text { MI } \\
\text { Mo } \\
\text { S } \\
\text { 白土 }\end{array}\right.$ & $\begin{array}{l}1.1 \\
1.9 \\
2.5 \\
3.4\end{array}$ & $31\left(29^{\circ}\right)$ & 46.0 & 5.0 & $434 \pm 3$ & 60 & 145 & 124 \\
\hline 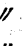 & 25 & " & " & " & & $37\left(29^{\circ}\right)$ & 40.0 & 4.5 & $422 \pm 2$ & 60 & 143 & 130 \\
\hline " & 26 & " & "I & $\mathrm{N}^{1 /} \mathrm{O}$ & 1. & $32\left(35^{\circ}\right)$ & 36.0 . & 4.9 & $435 \pm 1$ & 30 & 149 & 144 \\
\hline 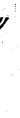 & 41 & $\begin{array}{l}\mathrm{NiO}+\mathrm{MoO}_{3} \\
+\mathrm{S}+\text { 白土 }\end{array}$ & 10 & $\left\{\begin{array}{l}\mathrm{MoO}_{3} \\
\mathrm{~S} \\
\text { 白土 }\end{array}\right.$ & $\begin{array}{l}2.8 \\
2.5 \\
3.4\end{array}$ & $41\left(25^{\circ}\right)$ & 36.4 & 4.0 & $436 \pm 2$ & 60 & 163 & 42 \\
\hline I & 43 & $\begin{array}{l}\text { Fe-Mo-S-白 } \\
\text { 土 }\end{array}$ & 10 & $\left\{\begin{array}{l}\mathrm{Fe} \\
\mathrm{Mo} \\
\mathrm{S} \\
\text { 白土 }\end{array}\right.$ & $\begin{array}{l}1.1 \\
1.9 \\
2.5 \\
3.4\end{array}$ & $34\left(24^{\circ}\right)$ & 42.7 & 4.9 & $434 \pm 1$ & 60 & 154 & 129 \\
\hline & 81 & " & "I & " & & $40\left(19^{\circ}\right)$ & 37.8 & 4.0 & $419 \pm 1$ & 60 & 150 & 129 \\
\hline
\end{tabular}


處理油は包收率，比重，生成水分等を測定したる後，一定量を探り分溜した。分溜分は，( $\left.180^{\circ}\right),\left(180 \sim 275^{\circ}\right),\left(275 \sim 300^{\circ}\right)$ の 3 溜分飞分方，各溜分飞つを $90 \% \mathrm{H}_{2} \mathrm{SO}_{4}$ とるる損失\%， $d_{4}^{250}, n_{D}^{250}$ を測定し，之等性狀の比較立立に水素渻費量の多少に依り各種觸媒の能力を比較した。 良く水素の添加せられをる溜分程大體に於て $90 \% \mathrm{H}_{2} \mathrm{SO}_{4}$ による損失\%， $d_{4}^{250} ， n_{D}^{250}$ は小とな るは，觸媒の種類に依り反應中に於ける分解樣式を異にするためであらう。文， $d_{4}^{250}, n_{D}^{25 \circ}$ 等㳉 嚴密に汁 $90 \% \mathrm{H}_{2} \mathrm{SO}_{4}$ による損失\%に比例せず，生成ガスは主として $\mathrm{H}_{2}$ 及び $\mathrm{C}_{n} \mathrm{H}_{2 n+2}$ にし て處理溫度同一をる場合と雖も觸媒の種類に依り分解樣式を異にするため $\mathrm{C}_{n} \mathrm{H}_{2 n+2}$ の量は一 定ならず。以上の結果より實驗 No.18の Ni-Mo-S-白土をる觸媒を使用した場合最も良好な

\begin{tabular}{|c|c|c|c|c|c|c|c|c|c|c|c|c|c|}
\hline \multirow{2}{*}{\multicolumn{2}{|c|}{ 實驗番號 }} & \multirow[b]{2}{*}{$\begin{array}{l}\text { 包 } \\
\text { 收 } \\
\text { 率 }\end{array}$} & \multirow[b]{2}{*}{$\begin{array}{l}\text { 包收油 } \\
\text { 比 重 }\end{array}$} & \multirow[b]{2}{*}{$\begin{array}{l}\text { 包收油 } \\
\text { 色 彩 }\end{array}$} & \multirow{2}{*}{$\begin{array}{l}\text { 第 } \\
\text { 生成 } \\
\text { 水分 }\end{array}$} & \multicolumn{7}{|c|}{ 表 } & \multirow[b]{2}{*}{$\begin{array}{l}\text { 蒸溜 } \\
\text { 殘渣 }\end{array}$} \\
\hline & & & & & & $\sim 180$ & $\begin{array}{r}180 \sim \\
200\end{array}$ & $\begin{array}{r}200 \sim \\
230\end{array}$ & $230 \sim$ & $\begin{array}{r}250 \sim \\
275\end{array}$ & $\begin{array}{r}275 \sim \\
300\end{array}$ & $300 \sim$ & \\
\hline & 71 & $98.0 \%$ & $0.850^{350}$ & 黃褐 & $\%$ & 7.7 & 2.0 & 5.3 & 4.7 & 7.0 & 9.3 & 62.7 & \\
\hline " & 70 & 98.0 & $0.830^{35^{\circ}}$ & " & & 16.7 & 4.0 & 7.0 & 7.7 & 9.3 & 9.3 & 45.2 & \\
\hline " & 72 & 95.1 & $0.831^{20^{\circ}}$ & 綠褐 & & 22.7 & 3.3 & 9.0 & 6.7 & 8.7 & 8.7 & 40.0 & ' \\
\hline " & 75 & 96.0 & $0.865^{35^{0}}$ & 褐 & & 2.7 & 1.0 & 4.3 & 3.0 & 7.3 & 8.7 & 67.3 & \\
\hline II & 74 & 95.0 & $0.864^{30^{\circ}}$ & "I & & 7.7 & 1.8 & 5.7 & 3.5 & 9.2 & 8.8 & 62.6 & \\
\hline " & 73 & 95.0 & $0.853^{200}$ & $\pi$ & & 22.7 & 4.3 & 8.3 & 7.3 & 8.5 & 8.3 & 40.0 & \\
\hline " & 5 & 94.0 & $0.827^{300}$ & 黃赤 & 3.2 & 21.3 & 4.0 & 10.0 & 6.7 & 8.3 & 8.7 & 37.7 & 2.4 \\
\hline " & 47 & 95.0 & $0.841^{300}$ & " & 2.4 & 11.3 & 2.7 & 6.3 & 4.3 & 7.7 & 8.7 & 58.0 & 1.4 \\
\hline "I & 7 & 96.0 & $0.840^{300}$ & 赤黃 & 2.0 & 20.3 & 3.7 & $8 \cdot 3$ & 6.7 & 9.3 & 8.7 & 38.3 & 5.2 \\
\hline "I & 45 & 96.0 & $0.839^{300}$ & 暗黃 & 1.1 & 11.3 & 2.7 & 6.7 & 5.3 & 6.7 & 8.3 & 54.7 & 2.4 \\
\hline " & 8 & 93.6 & $0.831^{25^{\circ}}$ & 黃紅 & 2.1 & 23.7 & 3.7 & 11.7 & 7.0 & 9.3 & 8.7 & 32.7 & 2.8 \\
\hline " & 46 & 95.0 & $0.845^{300}$ & 紅黃 & 1.6 & 11.3 & 2.7 & 5.0 & 6.7 & 8.0 & 10.7 & 52.3 & 2.2 \\
\hline " & 4 & 94.6 & $0.822^{250}$ & 黃紅 & 3.2 & 22.3 & 4.7 & 9.7 & 6.0 & 9.7 & 9.7 & 35.3 & 2.1 \\
\hline$" 1$ & 48 & 95.0 & $0.830^{300}$ & 橙黃 & 2.3 & 11.3 & 3.0 & 6.3 & 5.3 & 9.0 & 8.3 & 54.0 & 1.6 \\
\hline "I & 12 & 92.6 & $0.828^{250}$ & 黃紅 & 1.8 & 23.3 & 4.7 & 9.3 & 7.7 & 8.7 & 8.0 & 37.7 & \\
\hline " & 19 & 96.0 & $0.835^{300}$ & " & 2.7 & 13.7 & 3.7 & 6.3 & 6.7 & 10.3 & 7.7 & 49.3 & 2.0 \\
\hline "I & 80 & 96.0 & $0.838^{35^{\circ}}$ & " & 1.5 & 5.3 & 1.7 & 3.3 & 6.7 & 6.7 & 9.0 & 67.7 & \\
\hline " & 20 & 97.4 & $0.845^{300}$ & 黃褐 & 2.7 & 12.3 & 3.3 & 7.7 & 6.0 & 8.3 & 8.7 & 50.0 & 2.4 \\
\hline " & 76 & 97.0 & $0.849^{35^{\circ}}$ & " & 1.9 & 5.3 & 1.3 & 3.7 & 6.0 & 6.3 & 9.3 & 66.0 & \\
\hline " & 21 & 98.0 & $0.833^{300}$ & 黄紅. & 2.9 & 14.3 & 3.7 & 8.2 & 6.8 & 8.3 & 9.0 & 46.3 & 3.0 \\
\hline " & 78 & 97.0 & $0.844^{350}$ & 黃紅 & 3.0 & 3.3 & 1.7 & 3.3 & 6.7 & 6.0 & 9.0 & 69.3 & \\
\hline "I. & 23 & 97.0 & $0.827^{30^{\circ}}$ & 綠黃 & 3.2 & 14.7 & 3.3 & 8.0 & 7.7 & 10.0 & 7.2 & 46.0 & 2.0 \\
\hline 11 & 79 & 97.0 & $0.834^{350}$ & ," & $1: 6$ & 5.3 & 1.7 & 0.1 & 4.0 & 7.7 & 10.3 & 66.6 & \\
\hline /" & 18 & 95.0 & $0.827^{300}$ & 黃紅 & 3.4 & 13.0 & 3.7 & 8.3 & 7.3 & 8.7 & 9.7 & 44.3 & 1.0 \\
\hline " & 25 & 97.0 & $0.838^{350}$ & " & 3.0 & 10.5 & 3.0 & 7.8 & 7.9 & 9.6 & 10.9 & 49.6 & \\
\hline " & 26 & 97.1 & $0.829^{35^{\circ}}$ & "1 & 2.9 & 11.4 & 3.5 & 7.7 & 8.1 & 9.3 & 9.6 & 49.8 & \\
\hline " & 41 & 94.0 & $0.842^{350}$ & 黃褐 & 1.0 & 12.0 & 2.7 & 7.3 & 6.0 & 9.0 & 7.8 & 52.0 & \\
\hline "I & 43 & 97.0 & $0.823^{350}$ & 橙黃 & 3.0 & 11.7 & 3.3 & 5.3 & 6.0 & 8.3 & 8.7 & 52.7 & 2.0 \\
\hline II & 81 & 98.0 & $0.839^{350}$ & "I & 2.9 & 3.3 & 1.3 & 3.3 & 4.7 & 8.7 & 8.0 & 67.7 & \\
\hline
\end{tabular}


る結果を示した。本觸媒よ $\mathrm{Ni}(\mathrm{OH})_{3},\left(\mathrm{NH}_{4}\right)_{2} \mathrm{MoO}_{4}$ をアンモニア水溶液として混合せるものに $\mathrm{S}$ を混じ白土に吸着せしめたるものであつて Ni 及び Mo をかっる狀態て於て 混合せるもの は實驗 No.41 の如く Ni 及び Mo を夫三酸化物の形に於て混合したるもの或江實驗 No. 43 の如く Ni の代り K Fe を使用せるものよりも能力優秀をる事を知り得を。又，Moを單獨に 使用せる場合にても $\mathrm{MoO}_{3}$ の形に於けるより夕 $\left(\mathrm{NH}_{4}\right)_{2} \mathrm{MoO}_{4}$ なる形に於て使用する方，又更 飞 $\mathrm{MoS}_{3}$ なる形に於て使用する方が優秀である。又 $\mathrm{MoO}_{3}$ K S を添加せるものよりも $\mathrm{MoS}_{3}$ 或 は $\left(\mathrm{NH}_{4}\right)_{2} \mathrm{MoO}_{4}$ の形飞於て使用する方が優秀なる能力を示す。 $\mathrm{Fe}, \mathrm{Cu}$ 等浪好なる結果を示 さず，3 時間處理すと雖も上述の如き触媒を使用し1時間處理せる場合よりも遙に劣つて居る。

\begin{tabular}{|c|c|c|c|c|c|c|c|c|c|c|c|c|}
\hline \multirow{2}{*}{\multicolumn{2}{|c|}{$\begin{array}{l}\text { 䩈 } \\
\text { 驗 } \\
\text { 番 } \\
\text { 號 }\end{array}$}} & \multicolumn{3}{|c|}{$\sim 180^{\circ} \mathrm{C}$} & \multicolumn{3}{|c|}{$180 \sim 275^{\circ} \mathrm{C}$} & \multicolumn{3}{|c|}{$275 \sim 300^{\circ} \mathrm{C}$} & \multicolumn{2}{|c|}{$\begin{array}{l}300^{\circ} \mathrm{C} \text { 以上溜 } \\
\text { 分パラフィン竄 }\end{array}$} \\
\hline & & 捛 12 & $d_{4^{\circ}}^{25^{\circ}}$ & $n_{D}^{25^{\circ}}$ & る指 & $d_{4 \circ}^{250}$ & $n_{D}^{25^{\circ}}$ & $\begin{array}{l}90 \% \mathrm{H}_{2} \mathrm{SO} \\
\text { にるる損失\% }\end{array}$ & $d_{10}^{250}$ & $n_{D}^{25^{\circ}}$ & $\begin{array}{c}\text { 含有量 } \\
\mathrm{g} \%\end{array}$ & ${ }_{{ }^{\circ} \mathrm{F}}^{\mathrm{M} . \mathrm{P}}$ \\
\hline & 71 & 12.2 & 0.7351 & 1061 & 20.2 & 0.8380 & 1.4592 & 20.8 & 0.8543 & .4707 & 24.1 & 120. \\
\hline "I & 70 & 2 & 0.7234 & 1.3973 & 16.2 & 0.8310 & 1.4570 & 18.2 & 0.85 & 1.4715 & 17.4 & 28 \\
\hline "1 & 72 & 118 & 0.7190 & 948 & 17.6 & 0.8340 & 1.4588 & 23.0 & 0.86 & .4781 & 15.0 & 24. \\
\hline "I & 75 & & 0.7456 & 089 & 24.4 & 0.8401 & 1.4590 & 26.4 & 0.859 & 1.4706 & 24.6 & 27. \\
\hline " & 74 & 184 & 0.74 & 1055 & 22.2 & 0.8400 & 1.4578 & 24.6 & 86 & 1.4715 & 8.3 & 26. \\
\hline ". & 73 & & 0.7141 & 3941 & 20.8 & 0.8310 & 1.4556 & 26.4 & 0.87 & 1.4788 & 10.5 & 26. \\
\hline "I & 5 & 7.6 & 0.7394 & 20.0 & 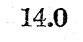 & 0.8310 & 1.4571 & 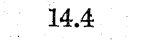 & 0.854 & 1.4714 & 20.2 & 20 \\
\hline "I & 47 & 5.6 & 0.7461 & 039 & 15.4 & 0.8289 & 1.4550 & 15.8 & .8492 & 1.4670 & 23.2 & 21. \\
\hline " & 7 & 0 & 0.7483 & 1.4046 & 15.8 & 0.8421 & 1.4619 & 20.2 & 0.862 & 1.4770 & & \\
\hline " & 45 & 210. & 0.7456 & 086 & 16.8 & 0.8346 & 1.4556 & 20.8 & 8527 & 1.4670 & & \\
\hline "I & 8 & 8.0 & 0.7381 & 1.4016 & 18.6 & 0.8439 & 1.4632 & 0.4 & 864 & 1.4780 & & \\
\hline " & 46 & 12.4 & 0.7245 & 026 & 0 & $0.836 t$ & 1.4569 & 2 & 0.85 & 1.4702 & 24.9 & 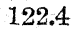 \\
\hline "I & 4 & 5 & 0.7402 & .041 & 10.2 & 0.8270 & 1.4550 & 1.8 & .0000 & 1.4699 & & \\
\hline " & 48 & 5 & 0.7370 & 1053 & 2.4 & 0.8238 & 1.4547 & 3.2 & 0.844 & 1.4650 & & \\
\hline " & 12 & & 0.73 & 1 & 0 & 0.8323 & 589 & 1.0 & 0.83 & 1.4736 & 8 & \\
\hline ") & 19 & 13.8 & 0.7439 & 4080 & 10.6 & 0.8358 & 1.4590 & 2.0 & 0.843 & 1.4712 & 22.1 & 122.4 \\
\hline " & 80 & 7.0 & o & 7 & 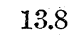 & 0.8280 & 4535 & 0 & 0.8420 & 4642 & $\cdots$ & o. \\
\hline " & 20 & 8 & 0.7409 & 4068 & 19.2 & 0.8401 & 1.4632 & 8.4 & 80 & .4739 & 4.3 & 24.5 \\
\hline "1. & 76 & 10.4 & 0.7442 & 76 & 19.4 & 0.8 & 70 & 9.8 & ( & 67 & 3.3 & 21.8 \\
\hline "I & 21 & 8.8 & 0.7495 & 1.4054 & 14.6 & 0.0300 & 1.4580 & 4.0 & 35 & 4690 & 0.5 & 21.0 \\
\hline " & 78 & 9.6 & 0.7530 & 1.4127 & 15.2 & 0.8320 & 4565 & 5.2 & 0.846 & 4658 & 5.6 & 122.3 \\
\hline " & 23 & 8.6 & 7458 & .4042 & $x^{2}$ & 0.0800 & .4543 & 9.2 & 急 & sot & 6 & 124.4 \\
\hline " & 79 & 5.6 & 0.7520 & 1.4021 & 10.6 & 0.8231 & 1.4562 & 11.0 & 0.8400 & 1.4663 & 26.4 & 120.9 \\
\hline$"$ & 18 & & 44 & 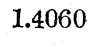 & 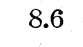 & . & 0 & 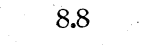 & & 5 & & \\
\hline "I & 25 & 5.8 & 0.7456 & 1.4093 & 9.2 & 0.8335 & 1.4559 & 9.8 & 0.0 & 1.4725 & & \\
\hline " & 26 & 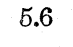 & 0.7450 & 82 & 9.3 & 0.8330 & 1.4560 & 9.2 & 0.8 & 1.4625 & 4.2 & 21.3 \\
\hline " & 41 & 0.0 & 0.7252 & 1.5001 & 15.0 & 0020 & 1.4567 & 17.0 & 0020 & 1.4681 & 4.7 & 19. \\
\hline " & 43 & 5.8 & 0.7327 & .4079 & 10.2 & 8238 & .4543 & 10.2 & 0.8442 & 1.4648 & 24.1 & 20.5 \\
\hline & 81 & 1.0 & 0.7530 & 1.4116 & 13.8 & 0.8302 & 1.4556 & 14.6 & 0.8441 & 1.4640 & 31.3 & 123. \\
\hline
\end{tabular}


第 $: \quad 9$

\begin{tabular}{|c|c|c|c|c|c|c|c|}
\hline 實驗 & 號 & $\mathrm{CO}_{2}$ & $\mathrm{C}_{n} \mathrm{H}_{2 n}$ & $\mathrm{CO}$ & $\mathrm{H}_{2}$ & $\mathrm{C}_{n} \mathrm{H}_{2 n+2}$ & $n$ \\
\hline & 71 & 0.2 & 0.4 & 0.1 & 90.5 & 10.3 & 1.7 \\
\hline "I & 70 & 0.2 & 0.2 & 0.3 & 83.5 & 16.3 & 1.0 \\
\hline " & 72 & 0.2 & 1.0 & 0.2 & 82.5 & 18.2 & 1.3 \\
\hline " & 75 & 0.3 & 2.6 & 0.4 & 92.6 & 7.3 & 0.9 \\
\hline "I & 74 & 0.1 & 0.2 & 0.6 & 87.3 & 12.1 & 1.5 \\
\hline " & 73 & 0.2 & 0.2 & 0.2 & 80.1 & 20.2 & 1.6 \\
\hline " & 5 & 0.3 & 0.1 & 0.2 & 81.2 & 17.1 & 1.5 \\
\hline " & 47 & 0.2 & 0.1 & 0.3 & 90.5 & 9.4 & 1.1 \\
\hline "I & 7 & 0.3 & 0.3 & 0.2 & 78.1 & 21.9 & 1.0 \\
\hline "I & 45 & 0.2 & 0.5 & 0.1 & 83.7 & 15.3 & 1.8 \\
\hline "I & 8 & 0.2 & 0.2 & 0.1 & 76.7 & 21.5 & 1.0 \\
\hline " & 46 & 0.3 & 0.3 & 0.2 & 88.9 & 13.9 & 1.1 \\
\hline 11 & 4 & 0.1 & 0.6 & C.2 & 73.2 & 32.3 & 2.0 \\
\hline "I & 48 & 0.2 & 0.4 & 0.3 & 95.4 & 7.3 & 1.1 \\
\hline & & & & 0.3 & 77 & 23.8 & \\
\hline
\end{tabular}

\begin{tabular}{|c|c|c|c|c|c|c|c|}
\hline 色驗 & 番號 & $\mathrm{CO}_{2}$ & $\mathrm{C}_{n} \mathrm{H}_{2 n}$ & $\mathrm{CO}$ & $\mathrm{H}_{2}$ & $\mathrm{C}_{n} \mathrm{H}_{2 n+2}$ & $n$ \\
\hline No & 19 & 0.1 & 0.5 & 0.0 & 85.6 & 17.9 & 1.4 \\
\hline " & 80 & 0.1 & 0.2 & 0.3 & 94.6 & 5.8 & 1.1 \\
\hline "I & 20 & 0.1 & 0.5 & 0.3 & 90.0 & 12.7 & 0.9 \\
\hline "I & 76 & 0.3 & 0.2 & 0.2 & 95.2 & 5.5 & 1.3 \\
\hline " & 21 & 0.3 & 0.3 & 0.2 & 89.3 & 13.9 & 1.0 \\
\hline "I & 78 & 0.2 & 0.3 & 0.2 & 92.5 & 6.6 & 0.9 \\
\hline "I & 23 & 0.0 & 0.4 & 0.0 & 84.0 & 17.2 & 1.0 \\
\hline "I & 79 & 0.2 & 0.2 & 0.1 & 93.5 & 6.7 & 1.2 \\
\hline " & 18 & 0.2 & 0.5 & 0.3 & 84.0 & 17.5 & 2.3 \\
\hline "I & 25 & 0.2 & 0.3 & 0.3 & 87.5 & 14.2 & 1.5 \\
\hline "I & 26 & 0.1 & 0.4 & 0.3 & 86.7 & 15.8 & 2.0 \\
\hline "I & 41 & 0.3 & 0.4 & 0.4 & 90.0 & 12.6 & 1.8 \\
\hline "I & 43 & 0.1 & 0.2 & 0.0 & 84.0 & 21.6 & 1.9 \\
\hline "I & 81 & 0.3 & 0.5 & 0.2 & 90.3 & 9.8 & 1.4 \\
\hline
\end{tabular}

實驗 No. 19，20，21，23，18 飞於て明かなる如く，Ni-Mo-S-白土なる 4 物質系をなせるも のは其の任意の 1 物質を除き 3 物質系として使用せる場合よりも優秀なる能力を有す。斯か る觸媒を使用する場合 $\mathrm{S}$ は一部 $\mathrm{H}_{2}$ と結合して $\mathrm{H}_{2} \mathrm{~S}$ となりなほ一部は $\mathrm{Mo}, \mathrm{Ni}$ と結合して $\mathrm{MoS}_{3}, \mathrm{NiS}$ を形成し之等が結合或は混合の狀態に於て觸媒としての能力を增進するものと推 察さる。

（3）觸媒に對する硫黃添加量，處理溫度，處理時間の影響

(i) 觸媒飞對する硫黃添加量の影響

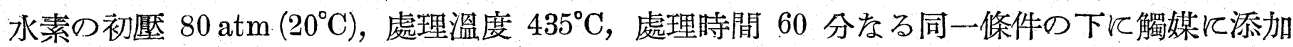
すべを Sの量を $1 \mathrm{~mol} よ り 4 \mathrm{~mol}$ 迄 $1 \mathrm{~mol}$ 宛增加して反應を行ひ各場合に於ける處理油の性 狀に及度す影響につき觀察した。其の結果法第 10〜14 表に示せる如くである。反應中消費せ

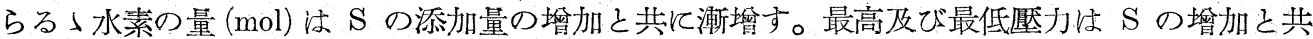
飞低下す。處理油汢 Sの添加量の增加之共に暗橙色より黄紅色飞變じ比重泜低減し，回收率及 び輕質油分の量法增加す。パラフィン蠟の含有量は $\mathrm{S} の$ 添加量 $3 \mathrm{~mol}$ 迄は燴加するが, $4 \mathrm{~mol}$ 添 加の場合漌飞減少す。分溜各溜分の $90 \% \mathrm{H}_{2} \mathrm{SO}_{4}$ 飞よる損失\%は $\mathrm{S}$ の添加量の增加と共に 減少し 3 及び $4 \mathrm{~mol}$ 添加の場合は略?同樣の值を探る。 $d_{40}^{250}, n_{D}^{250}$ : $230^{\circ} \mathrm{C}$ 上上の溜分飞於 ては $\mathrm{S}$ の添加量の錬加に從ひ減少す。生成がその成分は $\mathrm{S}$ の添加量と共に $\mathrm{C}_{n} \mathrm{H}_{2 n+2}$ の量を增 加す。以上の事實より觸媒飞一定量の $\mathrm{S}$ 老添加すれば其の水素添加能力を促進し，其の量注 3〜4 mol を適當とし，夫れ以上添加するも觸媒の能力增進に江效力なをもの小如くである。

(ii) 處理溫度の影響

水素の初厭 $80 \mathrm{~atm}\left(13^{\circ} \mathrm{C}\right)$, 處理時間 60 分，觸媒 $10 \%$ 等同一條件下飞處理溫度を 400 〜 $460^{\circ} \mathrm{C}$ 迄 $10^{\circ} \mathrm{C}$ 宛增加し，各處理溫度に於ける處理油の性狀の變化を觀察した。其の結果法第 
第 10 表

\begin{tabular}{|c|c|c|c|c|c|c|c|c|c|c|c|c|}
\hline \multirow{2}{*}{ 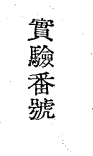 } & \multicolumn{3}{|c|}{ 觸 媒 } & & 水 & \multicolumn{2}{|l|}{ 素 } & \multirow{2}{*}{$\begin{array}{c}\text { 本理 } \\
\text { 均溫 } \\
\text { 處度 } \\
{ }^{\circ} \mathrm{C}\end{array}$} & \multirow{2}{*}{$\begin{array}{l}\text { 處 } \\
\text { 理 } \\
\text { 時 } \\
\text { 底 } \\
\text { min }\end{array}$} & \multirow{2}{*}{$\begin{array}{c}\text { 最 } \\
\text { 高 } \\
\text { 尉 } \\
\text { atm }\end{array}$} & \multirow{2}{*}{$\begin{array}{l}\text { 最力 } \\
\text { 高走溫 } \\
\text { 厴示度 } \\
{ }^{\circ} \mathrm{C}\end{array}$} & \multirow{2}{*}{$\begin{array}{c}\text { 最 } \\
\text { 倠 } \\
\text { 厴 } \\
\text { atm }\end{array}$} \\
\hline & 種 類 & & 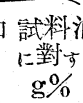 & $\begin{array}{c}\text { 由 初嬮 } \\
\text { 万(室溫) } \\
\text { atmm }\end{array}$ & $\begin{array}{c}\text { 終檿 } \\
\text { (室溫) } \\
\text { atm }\end{array}$ & $\begin{array}{l}\text { 減孷 } \\
\left(0^{\circ} \mathrm{C}\right) \\
\text { atm }\end{array}$ & $\begin{array}{c}\text { 水素 } \\
\text { 消費量 } \\
\text { mol }\end{array}$ & & & & & \\
\hline & Ni-Mo-S- & 1 & 8.2 & $80\left(20^{\circ}\right)$ & $40\left(17^{\circ}\right)$ & 36.9 & 3.8 & $434 \pm 2$ & 60 & 163 & 431 & 138 \\
\hline 83 & 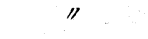 & 2 & 8.8 & "I & $37\left(15^{\circ}\right)$ & 39.4 & 4.1 & $435 \pm 1$ & " & 158 & 380 & 132 \\
\hline 84 & "I & 3 & 9.4 & " & $34\left(17^{\circ}\right)$ & 42.5 & 4.7 & $433 \pm 2$ & " & 156 & 416 & 130 \\
\hline 87 & " & 4 & 10.0 & " & $31\left(15^{\circ}\right)$ & 45.1 & 4.8 & $434 \pm 1$ & " & 152 & 410 & \\
\hline
\end{tabular}

第 11 表

\begin{tabular}{|c|c|c|c|c|c|c|c|c|c|c|c|c|c|}
\hline \multirow{2}{*}{$\begin{array}{l}\text { 瞍 } \\
\text { 驗 } \\
\text { 番 } \\
\text { 號 }\end{array}$} & \multirow{2}{*}{$\begin{array}{c}\text { 旬 } \\
\text { 收 } \\
\text { 卒 } \\
\text { vol \% }\end{array}$} & \multirow{2}{*}{$\begin{array}{c}\text { 回收油 } \\
\text { 比 重 } \\
d_{4 \circ}^{220}\end{array}$} & \multicolumn{2}{|c|}{ 包收油 } & \multirow{2}{*}{$\begin{array}{l}\text { 生成 } \\
\text { 水分 } \\
\text { vol\% }\end{array}$} & \multicolumn{8}{|c|}{ 分 溜 溜 分 $(\mathrm{vol} \%)$} \\
\hline & & & 色 & 彩 & & $\sim 150$ & $\begin{array}{r}150 \sim \\
180\end{array}$ & $\begin{array}{r}180 \sim \\
200\end{array}$ & $\begin{array}{r}200 \sim \\
230\end{array}$ & ${ }^{230} 250$ & $\underset{275}{250 \sim}$ & $\begin{array}{r}275 \sim \\
300\end{array}$ & $300-$ \\
\hline No. 82 & 95.7 & 0.830 & 暗 & 橙 & 3.1 & 7.0 & 3.7 & 2.2 & 6.0 & 6.0 & 7.8 & 10.0 & 57.5 \\
\hline "I 83 & 95.8 & 0.828 & 橙 & 黃 & 3.0 & 6.7 & 3.0 & 2.0 & 5.3 & 5.7 & 8.0 & 11.3 & 57.3 \\
\hline 84 & 95.7 & 0.822 & 黃 & 紅 & 3.5 & 7.3 & 3.3 & 3.0 & 6.3 & 5.7 & 9.2 & 10.2 & 54.3 \\
\hline 87 & 96.6 & 0.819 & "I & & 3.2 & 7.7 & 3.3 & 3.0 & 7.7 & 4.8 & 10.3 & 8.5 & 54.0 \\
\hline
\end{tabular}

第 12 表

$300^{\circ} \mathrm{C}$ 以上溜分パラフィン緛

\section{實驗番號}

No. 82

1) 83

" 84

\begin{tabular}{cc}
\hline 含有量 $\mathrm{g} \%$ & M. P. ${ }^{\circ} \mathrm{F}$ \\
27.8 & 12.15 \\
28.4 & 125.3 \\
32.6 & 126.4
\end{tabular}

\section{第 13 表}

\begin{tabular}{|c|c|c|c|c|c|c|c|c|c|c|c|c|}
\hline \multirow[b]{2}{*}{$\begin{array}{l}\text { 實 } \\
\text { 驗 } \\
\text { 番 } \\
\text { 號 }\end{array}$} & \multicolumn{3}{|c|}{$\sim-150^{\circ} \mathrm{C}$} & \multicolumn{3}{|c|}{$150 \sim 180^{\circ}$} & \multicolumn{3}{|c|}{$180 \sim 200^{\circ}$} & \multicolumn{3}{|c|}{$200 \sim 230^{\circ}$} \\
\hline & $\begin{array}{c}90 \% \\
\mathrm{H}_{2} \mathrm{SO}_{4} \\
\mathrm{~K}^{\mathrm{L}} \mathrm{z} \\
\text { 損失\% }\end{array}$ & $d_{4^{\circ}}^{250^{\circ}}$ & $n_{D}^{250}$ & $\begin{array}{c}90 \% \\
\mathrm{H}_{2} \mathrm{SO}_{4} \\
\kappa \\
\kappa \\
\text { 損失\% }\end{array}$ & $d_{4^{\circ}}^{250}$ & $n_{D}^{25^{\circ}}$ & 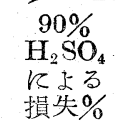 & $d_{40}^{2 b \circ}$ & $n_{D}^{25^{\circ}}$ & $\begin{array}{c}90 \% \\
\mathrm{H}_{2} \mathrm{SO}_{4} \\
\mathrm{~K} \leftarrow 3 \\
\text { 損失\% }\end{array}$ & $d_{4^{\circ}}^{250}$ & $n_{D}^{25^{\circ}}$ \\
\hline No. 82 & 5.6 & 0.7010 & 1.3892 & 6.6 & 0.7700 & 1.4235 & 8.2 & 0.7858 & 1.4358 & 10.0 & 0.8130 & 1.4476 \\
\hline 83 & 5.0 & 0.7032 & 1.3904 & 5.4 & 0.7711 & 1.4245 & 6.5 & 0.7828 & 1.4352 & 7.8 & 0.8120 & 1.4456 \\
\hline " 84 & 5.0 & 0.7025 & 1.3895 & 5.0 & 0.7702 & 1.4226 & 5.4 & 0.7923 & 1.4351 & 6.8 & 0.8120 & 1.4465 \\
\hline \multirow[t]{2}{*}{ 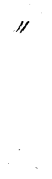 } & 4.0 & 0.7071 & 1.3892 & 5.4 & 0.7722 & $\cdot 1.4235$ & 6.3 & 0.7925 & 1.4358 & 6.6 & 0.8132 & 1.4461 \\
\hline & \multicolumn{4}{|c|}{$230 \sim 250^{\circ}$} & \multicolumn{4}{|c|}{$250 \sim 275^{\circ}$} & \multicolumn{4}{|c|}{$275 \sim 300^{\circ}$} \\
\hline$\checkmark$ & $\begin{array}{l}90 \% \mathrm{H} \\
\text { よる指 }\end{array}$ & & $\overbrace{d_{40}^{250}}^{20^{\circ}}$ & $n_{D}^{25^{\circ}}$ & $\begin{array}{c}90 \% \\
53\end{array}$ & & $25^{\circ}$ & $n_{D}^{25^{\circ}}$ & $\begin{array}{l}90 \% 1 \\
2 る 1\end{array}$ & $\begin{array}{l}\mathrm{O}_{4} \mathrm{KR} \\
\%\end{array}$ & $d_{4 \circ}^{25 \circ}$ & $n_{D}^{25^{\circ}}$ \\
\hline No. 82 & 11.0 & & 0.8271 & 1.4549 & 11.8 & & .8352 & 1.4590 & 12.6 & & 0.8420 & 1.4663 \\
\hline 83 & 9.0 & & 0.8226 & 1.4524 & 8.2 & & .8319 & 1.4578 & 9.8 & & 0.8399 & 1.4622 \\
\hline 84 & 7.6 & & 0.8243 & 1.4530 & 7.8 & & 8318 & 1.4577 & 7.6 & & 0.8380 & 1.4620 \\
\hline 87 & 7.6 & & 0.8243 & 1.4533 & 7.6 & & .8312 & 1.1572 & 5.4 & & 0.8373 & 1.4610 \\
\hline
\end{tabular}




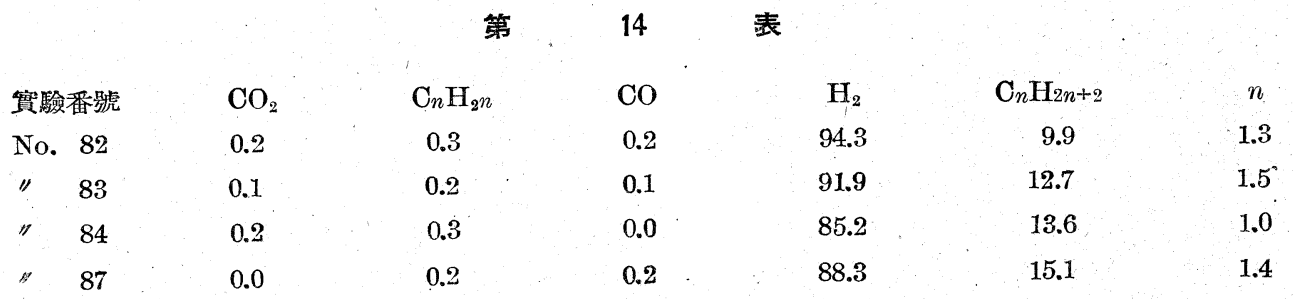

第 15 表（觸媒 Ni-Mo-S-白土 $10 \%$ )

\begin{tabular}{|c|c|c|c|c|c|c|c|c|c|}
\hline , & & & 水 & 素 & & & & & \\
\hline 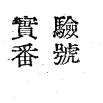 & $\begin{array}{c}\text { 處理溫度 } \\
{ }^{\circ} \mathrm{C}\end{array}$ & $\begin{array}{l}\text { 初 願) } \\
\text { (室) } \\
\text { atm }\end{array}$ & $\begin{array}{c}\text { 終 厴 } \\
\text { (室) } \\
\text { atm }\end{array}$ & $\begin{array}{c}\text { 減 厴 } \\
\left(0^{\circ} \mathrm{C}\right) \\
\text { atm }\end{array}$ & $\begin{array}{c}\text { 水 } \\
\text { 消霣量 } \\
\text { mol }\end{array}$ & $\begin{array}{l}\text { 處理 } \\
\text { 奎間 } \\
\text { min }\end{array}$ & $\begin{array}{l}\text { 最膏 } \\
\text { 壓力 } \\
\text { atm }\end{array}$ & 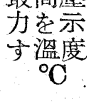 & $\begin{array}{l}\text { 最低 } \\
\text { 壓力 } \\
\text { atm }\end{array}$ \\
\hline No. 56 & $401 \pm 2$ & $80\left(13^{\circ}\right)$ & $40\left(14^{\circ}\right)$ & 38.4 & 4.1 & 60 & 156 & 395 & 130 \\
\hline 57 & $410 \pm 2$ & " & $36\left(15^{\circ}\right)$ & 42.3 & 4.5 & " & 152 & 409 & 128 \\
\hline " 58 & $420 \pm 1$ & " & $35\left(16^{\circ}\right)$ & 43.3 & 4.6 & "l & 152 & 420 & 130 \\
\hline " 53 & $431 \pm 2$ & " & $29\left(14^{\circ}\right)$ & 48.8 & 5.1. & "I & 150 & 402 & 129 \\
\hline " 59 & $439 \pm 3$ & " & $29\left(16^{\circ}\right)$ & 49.0 & 5.4 & "I & 156 & 410 & 134 \\
\hline " 60 & $449 \pm 2$ & " & $26\left(14^{\circ}\right)$ & 51.6 & 5.7 & "' & 154 & 416 & 136 \\
\hline " 61 & $461 \pm 2$ & " & $24\left(15^{\circ}\right)$ & 53.6 & 6.1 & " & 162 & 420 & 149 \\
\hline
\end{tabular}

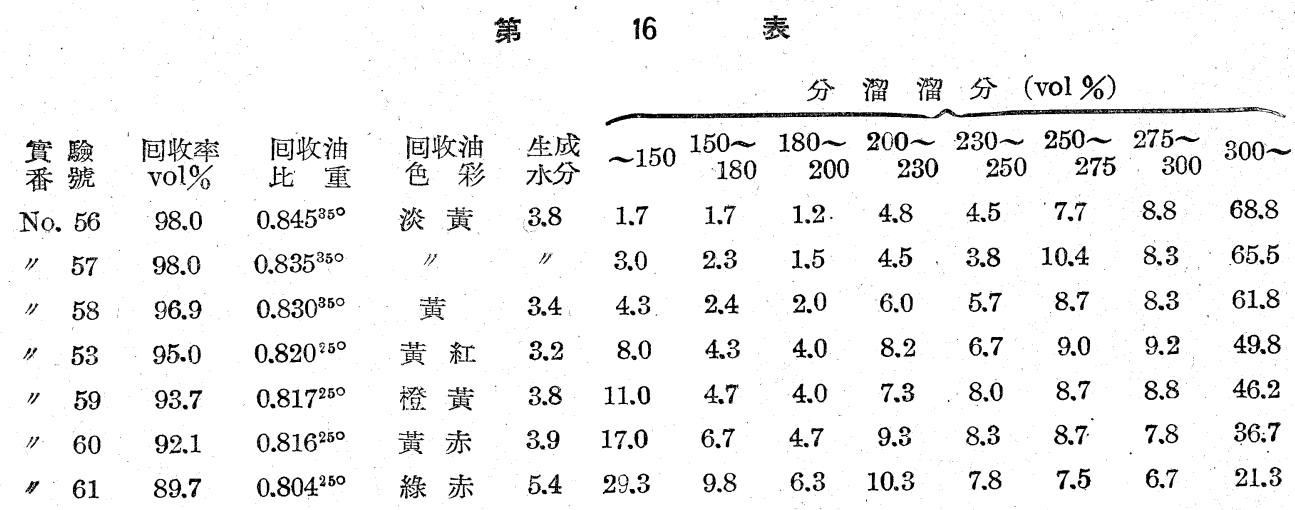

第 17 累

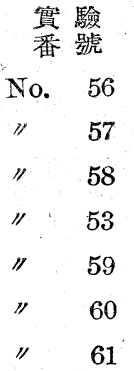

\begin{tabular}{|c|c|}
\hline \multicolumn{2}{|c|}{$300^{\circ} \mathrm{C}$ 以上溜分バラフィン既 } \\
\hline 含有量 $\mathrm{g} \%$ & M.P. ${ }^{\circ} \mathrm{F}$ \\
\hline 23.6 & 125.1 \\
\hline 24.9 & 125.8 \\
\hline 26.4 & 125.3 \\
\hline 29.7 & 125.4 \\
\hline 23.7 & 122.4 \\
\hline 23.6 & 121.3 \\
\hline 12.7 & 119.1 \\
\hline
\end{tabular}




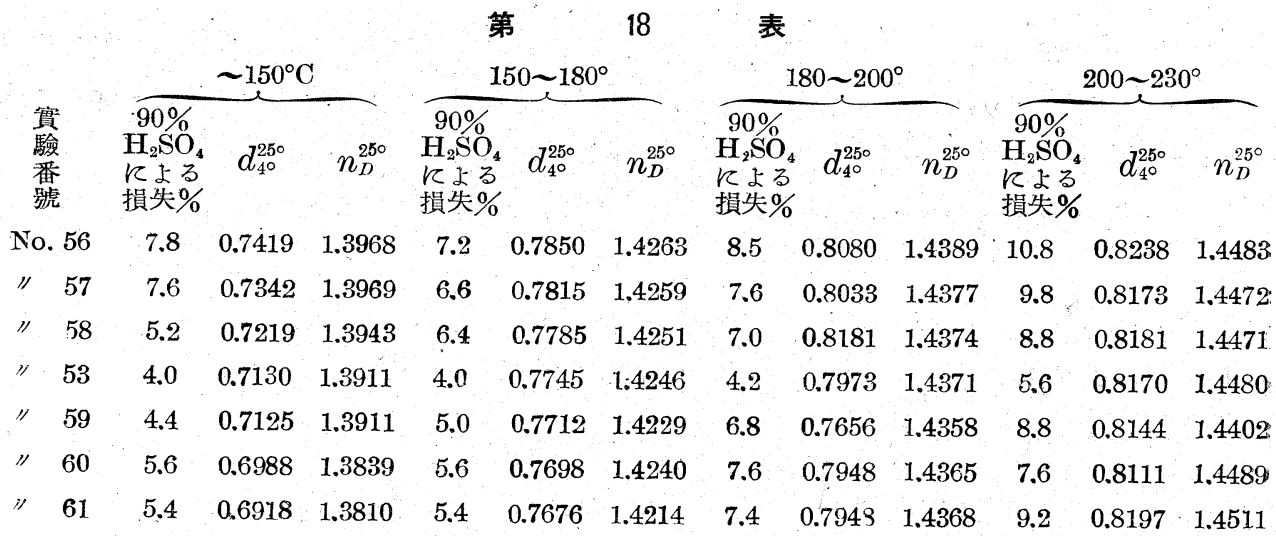

\begin{tabular}{|c|c|c|c|c|c|c|c|c|c|}
\hline & \multicolumn{3}{|c|}{$230 \sim 250^{\circ}$} & \multicolumn{3}{|c|}{$250 \sim 275^{\circ}$} & \multicolumn{3}{|c|}{$275 \sim 300^{\circ}$} \\
\hline & $\begin{array}{l}90 \% \mathrm{H}_{2} \mathrm{SO}_{4} \mathrm{~K} \\
\text { よる損失\% }\end{array}$ & $d_{4^{\circ}}^{25 \circ}$ & $n_{D}^{25^{\circ}}$ & $\begin{array}{l}90 \% \mathrm{H}_{2} \mathrm{SO}_{4} \mathrm{~K} \\
\text { よる損失\% }\end{array}$ & $d_{4 \circ}^{250}$ & $n_{D}^{25^{\circ}}$ & $\begin{array}{l}90 \% \mathrm{H}_{2} \mathrm{SO}_{4} \mathrm{~K} \\
よ る \text { 損失\% }\end{array}$ & $d_{4^{\circ}}^{25 \circ}$ & $n_{D}^{25^{\circ}}$ \\
\hline No. 56 & 9.6 & 0.8326 & 1.4528 & 10.8 & 0.8367 & 1.4573 & 10.8 & 0.8442 & 1.4618 \\
\hline 57 & 9.4 & 0.8279 & 1.4518 & 9.4 & 0.8343 & 1.4569 & 9.0 & 0.8422 & 1.4613 \\
\hline 58 & 9.4 & 0.8279 & 1.4525 & 9.8 & 0.8349 & 1.4570 & 9.8 & 0.8373 & 1.4621 \\
\hline 53 & 6.2 & 0.8281 & 1.4550 & 6.2 & 0.8326 & 1.4595 & 5.8 & 0.8388 & 1.4632 \\
\hline 59 & 7.0 & 0.8274 & 1.4550 & 9.0 & 0.8340 & 1.4598 & 8.6 & 0.8400 & 1.4643 \\
\hline 60 & 10.4 & 0.8289 & 1.4562 & 8.6 & 0.8376 & 1.4621 & 9.0 & 0.8439 & 1.4672 \\
\hline 61 & 11.6 & 0.8363 & 1.4638 & 12.6 & 0.8504 & 1.4721 & 15.4 & 0.8613 & 1.4738 \\
\hline
\end{tabular}

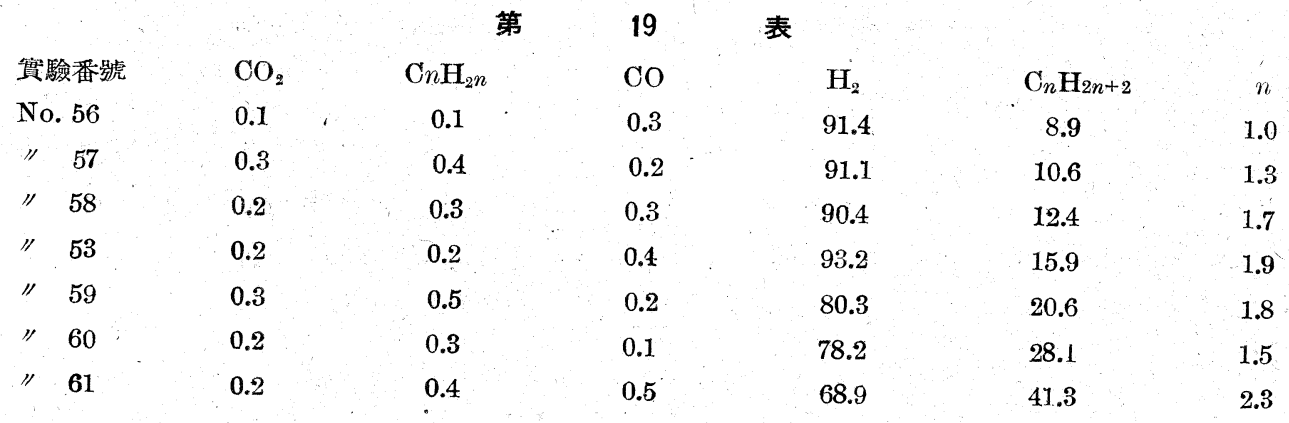

第 20 表（觸媒 Ni-Mo-S-白土 10\%）

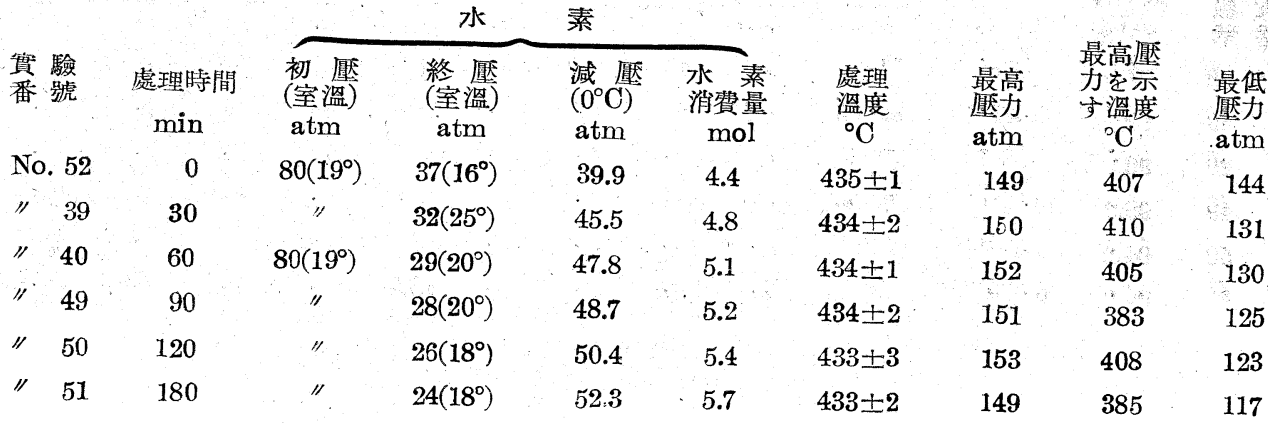


15〜19 表に示せる如くである。郎ち水素の消費量は處理溫度の上昇と共に增加し, 最高及び最 低壓力は初め處理溫度の上昇と共に減少するが, 或る一定溫度に於て最小值を示し，夫れ上上 の溫度に於ては分解の結果生成せる輕質油分の分熊の影響を受け漸增す。處理油は處理溫度の 上昇と共に黃色より綠色を帶ぶるに至り包收率及び比重を低減し輕質油分の量を增加す。含有

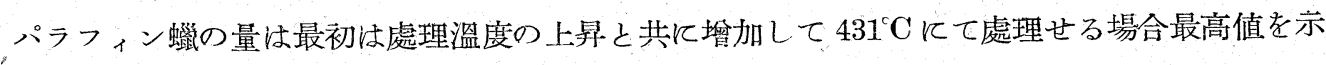
し，夫れ以上の溫度に於て法分解の結果次第に減少す。處理油の各溜分に於ける $90 \% \mathrm{H}_{2} \mathrm{SO}_{4}$ 損失\%江處理溫度の上昇と共に減少し， $431^{\circ} \mathrm{C}$ 飞て處理せる場合最小なる值を採り，夫れ上上 の溫度飞於て注分解生成物の重合のため反對飞燴加す。 $230^{\circ} \mathrm{C}$ 以上の油分に於ては $d_{4^{\circ}}^{250^{\circ}}, n_{D}^{25^{\circ}}$ の 值は大體て於て $90 \% \mathrm{H}_{2} \mathrm{SO}_{4}$ による損失\%に比例す。生成ガス中の $\mathrm{C}_{n} \mathrm{H}_{2 n+2}$ の量仗處理溫度 の上手と共に增加し $460^{\circ} \mathrm{C}$ の場合㳉 $41.3 \%$ に達した。以上の結果より處理溫度に㳉一定の 限界ありて此の溫度迄江處理油の不飽和度減少すれ共, 此の限界溫度以上の溫度に於ては却 て增加する傾向にあり，水素初壓 $80 \mathrm{~atm}$ とせる場合の限界溫度は $430^{\circ} \mathrm{C}$ である。

(iii) 處理時間の影響

水素の初壓 $80 \mathrm{~atm}\left(19^{\circ} \mathrm{C}\right)$, 處理溫度 $435^{\circ} \mathrm{C}$, 觸媒量等を一定に保ち處理時間を $0 \sim 180$ 分迄 30 宛增加して處理油の性狀に及仿す影響を檢した。其の結果汢第 20〜24 表に示せる如くであ る。處理溫度に達するに要する時間を一定にし, 處理時間 0 とは處理溫度に達すると同時に實 驗を中止せるものである。水素消費量注處理時間の延長と共飞增加すれ共, 處理溫度飞達する迄 に既に $4.8 \mathrm{~mol}$ を消費せられる處理油は處理時間の增加之共に橙色より黄色を呈するに至る。 な在分解反應のため處理時間の延長と共に包收率, 比重は減少し, 輕質油分の量は增加す。處理 油の各溜分に於ける $90 \% \mathrm{H}_{2} \mathrm{SO}_{4}$ による損失\%は處理時間の增加之共に減少するも， $d_{4^{\circ}}^{25 \circ}, n_{D}^{250}$ は或る一定時間に於て最小なる值を探り，夫れ以上に於ては反對飞增加する傾向にある。生成 ガス中 $\mathrm{C}_{n} \mathrm{H}_{2 n+2}$ の量注處理時間の增加之共飞漸增す。以上の如く能力優秀なる觸媒を使用す れば處理溫度 $435^{\circ} \mathrm{C}$ に於ては處理時間 0 なる場合に於ても處理油は相當飽和せられ, 餘りに長 時間處理するには $90 \% \mathrm{H}_{2} \mathrm{SO}_{4}$ とよる損失\%に於て注減少し得るも, 重合反應を伴ひ $d_{4^{\circ}}^{250}, n_{D}^{25^{\circ}}$ を增加せしむる傾向がある。

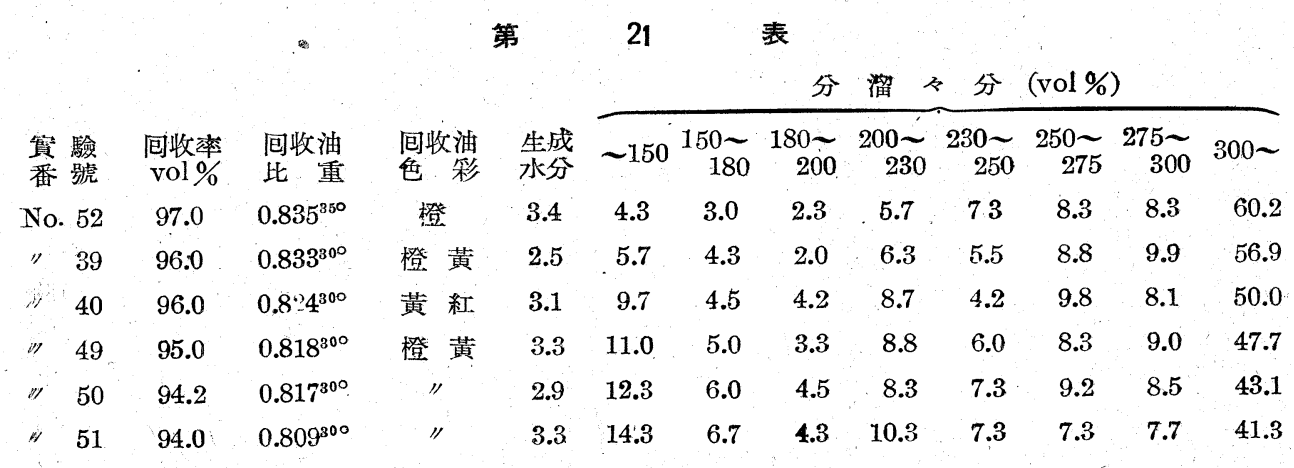




\begin{tabular}{|c|c|}
\hline \multicolumn{2}{|c|}{$200^{\circ} \mathrm{C}$ 以上溜分パラフィン醑 } \\
\hline 含有量 $\mathrm{g} \%$ & M. P. ${ }^{\circ} \mathrm{F}$ \\
\hline 27.9 & 124.2 \\
\hline 24.1 & 121.0 \\
\hline 26.3 & 118.1 \\
\hline 30.1 & 121.3 \\
\hline 32.2 & 118.9 \\
\hline 30.3 & 120.9 \\
\hline
\end{tabular}

\begin{tabular}{|c|c|c|c|c|c|c|c|c|c|c|c|c|}
\hline \multirow[b]{2}{*}{$\begin{array}{l}\text { 瞥 } \\
\text { 驗 } \\
\text { 番 } \\
\text { 號 }\end{array}$} & \multicolumn{3}{|c|}{$\sim 150^{\circ} \mathrm{C}$} & \multicolumn{3}{|c|}{$150 \sim 180^{\circ}$} & \multicolumn{3}{|c|}{$180 \sim 200^{\circ}$} & \multicolumn{3}{|c|}{$200 \sim 230^{\circ}$} \\
\hline & $\begin{array}{c}90 \% \\
\mathrm{H}_{2} \mathrm{SO}_{4} \\
\text { Kょる } \\
\text { 損失\% }\end{array}$ & $d_{4 \circ}^{25 \circ}$ & $n_{D}^{25^{\circ}}$ & $\begin{array}{c}90 \% \\
\mathrm{H}_{2} \mathrm{SO} \\
\mathrm{K} 5 z \\
\text { 損失\% }\end{array}$ & $d_{4^{\circ}}^{25^{\circ}}$ & $n_{D}^{25^{\circ}}$ & $\begin{array}{c}90 \% \\
\mathrm{H}_{2} \mathrm{SO}_{4} \\
r \downarrow る \\
\text { 損失\% }\end{array}$ & $d_{4^{\circ}}^{25^{\circ}}$ & $n_{D}^{25^{\circ}}$ & $\begin{array}{c}90 \% \\
\mathrm{H}_{z} \mathrm{SO}_{4} \\
\text { 亿文る } \\
\text { 損失\% }\end{array}$ & $d_{40^{\circ}}^{250}$ & $n_{D}^{25^{\circ}}$ \\
\hline No. 52 & 4.8 & 0.7217 & 1.3983 & 7.0 & 0.7781 & 1.4258 & 10.4 & 0.7985 & 1.4389 & 11.2 & 0.8229 & 1.4501 \\
\hline 39 & 5.0 & 0.7264 & 1.3942 & 5.2 & 0.7835 & 1.4270 & 8.4 & 0.7971 & 1.4388 & 9.2 & 0.8203 & 1.4492 \\
\hline 40 & 5.0 & 0.7143 & 1.3902 & 5.2 & 0.7766 & 1.4232 & 7.6 & 0.7954 & 1.4371 & 8.8 & 0.8202 & 1.4496 \\
\hline 49 & 3.0 & 0.7098 & 1.3908 & 3.2 & 0.7523 & 1.4208 & 5.0 & 0.7923 & 1.4339 & 5.6 & 0.8127 & 1.4458 \\
\hline 50 & 3.0 & 0.7138 & 1.3872 & 3.2 & 0.7159 & 1.4212 & 4.0 & 0.7922 & 1.4351 & 4.0 & 0.8120 & 1.4463 \\
\hline 51 & 4.5 & 0.7097 & 1.3892 & 3.0 & 0.7192 & 1.4222 & 4.0 & 0.7938 & 1.4360 & 3.8 & 0.8131 & 1.4473 \\
\hline
\end{tabular}

同上 (2)
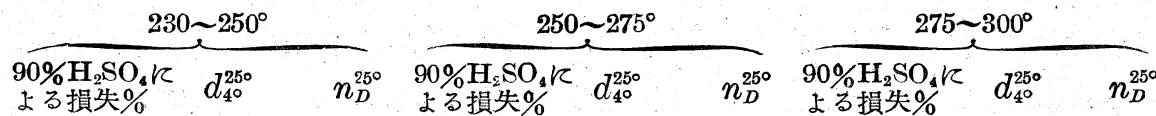

$\begin{array}{lllll}\text { No. } 52 & 12.0 & 0.8433 & 1.4560 \\ \text { " } 39 & 8.6 & 0.8301 & 1.4547 \\ \text { " } 40 & 7.6 & 0.8281 & 1.4550 \\ \text { " } 49 & 5.4 & 0.8254 & 1.4533 \\ \text { " } 50 & 5.4 & 0.8246 & 1.4535 \\ \text { " } 51 & 3.4 & 0.8256 & 1.4551\end{array}$

$\begin{array}{rrrrrr}11.8 & 0.8393 & 1.4611 & 12.6 & 0.8456 & 1.4658 \\ 9.0 & 0.8353 & 1.4585 & 9.2 & 0.8412 & 1.4625 \\ 9.2 & 0.8342 & 1.4590 & 9.0 & 0.8396 & 1.4631 \\ 5.4 & 0.8319 & 1.4577 & 5.4 & 0.8370 & 1.4612 \\ 4.8 & 0.8314 & 1.4591 & 4.4 & 0.8365 & 1.4624 \\ 3.6 & 0.8312 & 1.4593 & 3.6 & 0.8376 & 1.4630\end{array}$

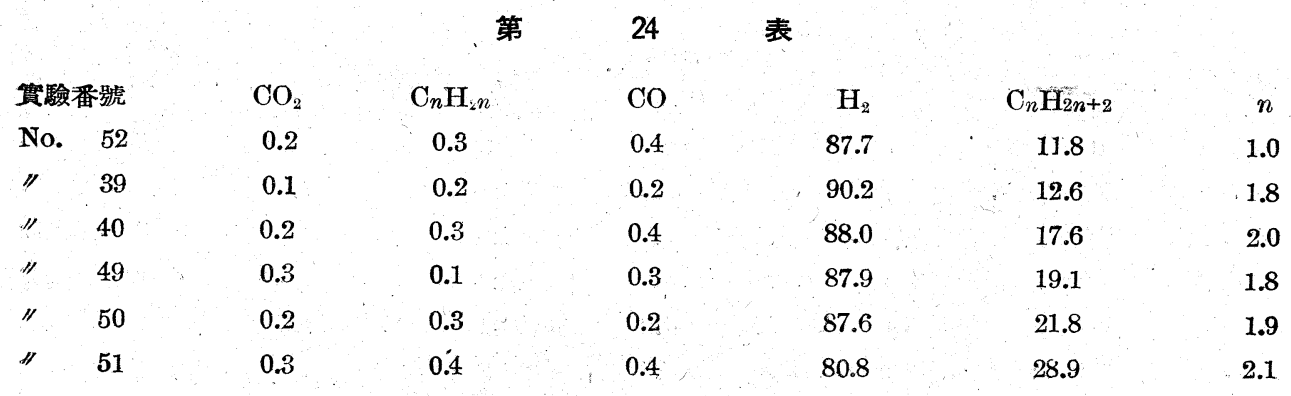


（4）水素初壓，水素純度の影響

(i) 水素初组の影響

處理溫度 $435^{\circ} \mathrm{C}$ ，處理時閒 60 分，觸媒 $10 \%$ として水素 の初塺を 0 よりり $120 \mathrm{~atm}$ 迄 $20 \mathrm{~atm}$ 宛增加して水素初壓の 處理油の性狀に及的す影響を檢した。水素の初壓 0 とは加壓 釜內の空內容積內の空氣を水素にて置換したのみのものであ る。其の結果壮第 25～29 表に示す如くである。水素消費量 汢初筀の燴加之共飞增加す。實驗 No. 91，初壓 0 なる場合 終壓が $10 \mathrm{~atm}$ を示す洁分解の結果生成せるガスに依る壓了 の增加である。最高壓力法初壓の增加と共に增加し，最高厴 力を示す㴧度は低下す。郎ち水素初壓の高き程油分の熱反應 老開始する洫度を低下し得。水素初嬮の變化と依る $\mathrm{P}_{0}$ 曲線 法初聶高き程其の傾斜度大となる。各實驗共加熱開始後 30 分にして既に水素は反應を始め, 此の時の壓力を最高として $\left(\mathrm{P}_{0 \mathrm{max}}\right), \mathrm{P}_{0}$ 曲線㳉下降し始め，處理時閒の經過と共に次第に低下 す。實驗を終れる時の庭力を $\left(\mathrm{P}_{0 \mathrm{~min}}\right)$ とすれば， $\left(\mathrm{P}_{0} \max -\mathrm{P}_{0 \mathrm{~min}}\right)$ は区應中消費せられたる水素 に依る壓力の減少である。初嬮低き程分解反應旺盛にして生成せる輕質油分の分厴の影響を受

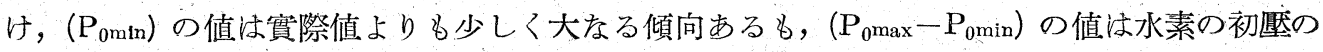

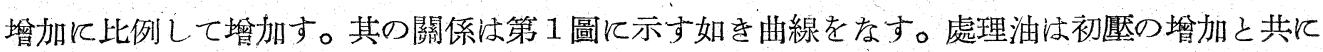
褐色より黃色に變じ逐に淡黃色となり，包收率注初嬮の燴加と共に分解反應を抑制せらるつた め增加し，初厴低き程分解竝に重合度共に大となり，輕質油を增加するに拘らず分解生成物の 比重を增大す。合有パラフィン蛝の量法初壓の增加に比例して增大す。各溜分に於ける $90 \%$

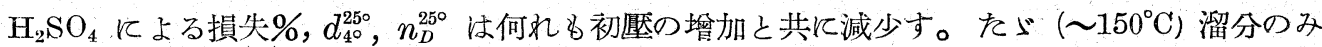
初壓低き程小となる。生成ガス中の $\mathrm{C}_{n} \mathrm{H}_{2 n+2}$ の量壮初㩐の增加と共飞分解反應を抑制せらる 小結果次第に減少す。以上の如く水素の初壓法高さ程分解反應汢抑制せられ，水素消費量壮增 加すると共に處理油の $90 \% \mathrm{H}_{2} \mathrm{SO}_{4}$ による損失 $\%, d_{4^{\circ}}^{25 \circ}, n_{D}^{25^{\circ}}$ 兹に生成分ス中の $\mathrm{C}_{n} \mathrm{H}_{2 n+2}$ の量 を減少し得る。
第 25 表 (解媒 Ni-Mo-S-白土 $10 \%$ )

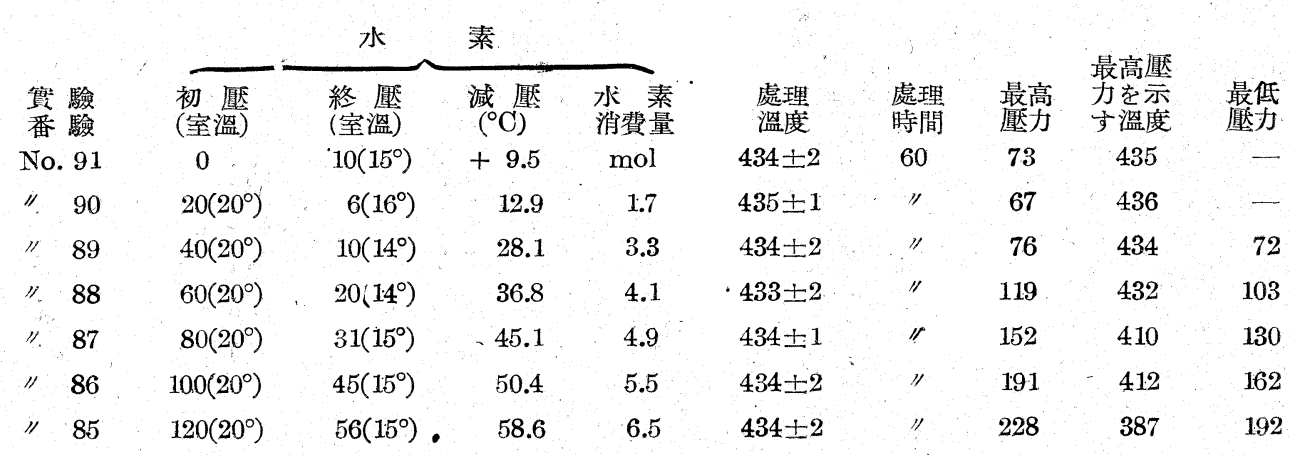




\begin{tabular}{|c|c|c|c|c|c|c|c|c|c|c|c|c|}
\hline & & & & & -26 & & 分 & 溜 & 分 & $(\operatorname{vol} \%)$ & & \\
\hline $\begin{array}{l}\text { 實 驗 } \\
\text { 番 號 }\end{array}$ & $\begin{array}{c}\text { 包收率 } \\
\text { vol \% }\end{array}$ & $\begin{array}{l}\text { 包收油 } \\
\text { 比重 }\end{array}$ & $\begin{array}{l}\text { 包收油 } \\
\text { 色 彩 }\end{array}$ & $\begin{array}{l}\text { 生成 } \\
\text { 水分 } \\
\text { vol \% }\end{array}$ & $\sim 150$ & $\begin{array}{r}150 \sim \\
180\end{array}$ & $\begin{array}{r}180 \sim \\
200\end{array}$ & $\begin{array}{r}200 \sim \\
230\end{array}$ & $\begin{array}{r}230 \sim 250 \\
250\end{array}$ & $\begin{array}{r}250 \sim \\
275\end{array}$ & $\begin{array}{r}275 \sim \\
300\end{array}$ & $300 \sim$ \\
\hline งo. 91 & 67.2 & $0.860^{250}$ & 濃 褐 & 2.1 & 21.7 & 6.7 & 5.3 & 9.5 & 7.3 & 8.5 & 7.2 & 33.1 \\
\hline " 90 & 84.3 & $0.870^{2.50}$ & $"$ & 3.0 & 14.7 & 5.7 & 4.5 & 9.8 & 5.7 & 8.0 & 9.7 & 41.3 \\
\hline 89 & 93.7 & $0.836^{250}$ & 褐 & 3.3 & 8.3 & 4.0 & 3.2 & 8.7 & 6.7 & 8.7 & 10.0 & 49.7 \\
\hline 88 & 93.7 & $0.826^{300}$ & 黃 褐 & 3.5 & 9.0 & 3.3 & 3.7 & 7.5 & 5.8 & 9.2 & 9.2 & 51.6 \\
\hline 87 & 96.6 & $0.819^{300}$ & 黃 紅 & 2.9 & 7.7 & 3.3 & 3.0 & 7.7 & 4.8 & 10.3 & 8.5 & 54.1 \\
\hline 86 & 97.6 & $0.820^{300}$ & 黃 綠 & 3.4 & 7.7 & 4.0 & 2.7 & 7.0 & 5.8 & 9.2 & 9.3 & 53.7 \\
\hline 85 & 98.0 & $0.825^{300}$ & 淡 綠 & 3.6 & 7.3 & 4.0 & 2.3 & 8.5 & 5.2 & 9.0 & 10.2 & 52.8 \\
\hline
\end{tabular}

第

27 表

實驗番號

No. 91

i) 90

1) 89

1) 88

II. 87

I) $\quad 86$

I) 85 $300^{\circ} \mathrm{C}$ 以上溜分バラフィン酳

\begin{tabular}{cc}
\hline 含有量 $\mathrm{g} \%$ & M. P. ${ }^{\circ} \mathrm{F}$ \\
\hline 14.5 & - \\
20.7 & 121.5 \\
25.9 & 124.1 \\
32.1 & 125.2 \\
35.6 & 125.4 \\
39.8 & 126.4 \\
& 126.8
\end{tabular}

\section{第}

28

表 (1)
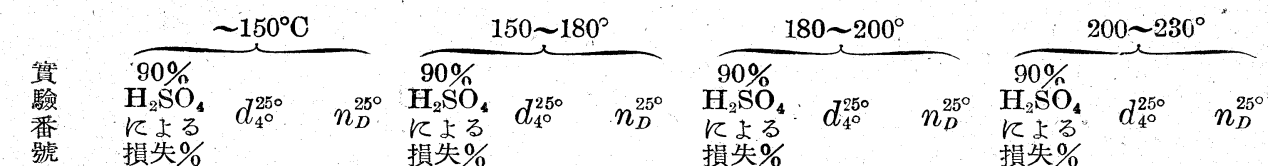
損失 $\%$ 損失\% 損失\%

$\begin{array}{llll}\text { No. } 91 & 12.2 & 0.6959 & 1.3856\end{array}$

12.8

$0.7791 \quad 1.4263$

15.6

$0.8050 \quad 1.4399$

17.0

$0.8261 \quad 1.4519$

$\begin{array}{lllllll}\text { "1 } & 90 & 10.2 & 0.7030 & 1.3891 & 10.0\end{array}$

$\begin{array}{ll}0.7786 & 1.4246\end{array}$

13.4

$0.8020 \quad 1.4390$

17.0

$0.8260 \quad 1.4518$

$\begin{array}{llllll}\text { " } & 89 & 5.4 & 0.6970 & 1.3846\end{array}$

6.8

$0.7730 \quad 1.4240$

$\begin{array}{lllll}12.0 & 0.8011 & 1.4889 & 14.4\end{array}$

0.8241 .1 .4515

1) 88

$\begin{array}{lll}4.2 & 0.6960 \quad 1.3864\end{array}$

6.4

$0.7725 \quad 1.4238$

$\begin{array}{lll}8.4 & 0.7970 & 1.4373\end{array}$

$\begin{array}{lll}9.2 & 0.8193 & 1.4501\end{array}$

1) 87

$\begin{array}{llll}4.0 & 0.7071 & 1.3892 & 5.4\end{array}$

$0.7722 \quad 1.4235$

$\begin{array}{lll}6.3 & 0.7925 & 1.4358\end{array}$

$\begin{array}{lll}6.6 & 0.8132 & 1.4461\end{array}$

$\begin{array}{lllllll}\text { /I } & 86 & 3.0 & 0.7070 & 1.3907 & 4.8\end{array}$

$0.7723 \quad 1.4230$

$\begin{array}{lll}5.0 & 0.7906 & 1.4325\end{array}$

$\begin{array}{lll}5.4 & 08106 & 1.4446\end{array}$

II 85

$$
\text { 同 上 (2) }
$$

\begin{tabular}{|c|c|c|c|c|c|c|c|c|c|}
\hline & \multicolumn{3}{|c|}{$230 \sim 250^{\circ}$} & \multicolumn{3}{|c|}{$250 \sim 275^{\circ}$} & \multicolumn{3}{|c|}{$275 \sim 300^{\circ}$} \\
\hline & $\begin{array}{l}90 \% \mathrm{H}_{2} \mathrm{SO}_{4} \mathrm{KK} \\
\text { よる損失\% }\end{array}$ & $d_{4^{\circ}}^{25 \circ}$ & $n_{D}^{45^{\circ}}$ & $\begin{array}{l}90 \% \mathrm{H}_{2} \mathrm{SO}_{4} \mathrm{Kr} \\
\text { よる損失\% }\end{array}$ & $d_{4^{\circ}}^{255^{\circ}}$ & $n_{D}^{25^{\circ}}$ & $\begin{array}{c}90 \% \mathrm{H}_{2} \mathrm{SO}_{4} \mathrm{~K} \\
\text { よる損失\% }\end{array}$ & $d_{4^{\circ}}^{250}$ & $n_{D}^{25^{\circ}}$ \\
\hline o. 91 & 20.0 & 0.8460 & 1.4635 & 21.0 & 0.8619 & 1.4745 & 23.6 & 0.8780 & 1.4862 \\
\hline " 90 & 19.0 & 0.8422 & 1.4618 & 20.0 & 0.8523 & 1.4710 & 22.2 & 0.8690 & 1.4800 \\
\hline " 89 & 15.6 & 0.8362 & 1.4595 & 16.2 & 0.8450 & 1.4662 & 17.0 & 0.8541 & 1.4719 \\
\hline 88 & 11.4 & 0.8290 & 1.4570 & 12.0 & 0.8370 & 1.4615 & 12.2 & 0.8448 & 1.4660 \\
\hline 87 & 7.6 & 0.8243 & 1.4533 & 7.6 & 0.8312 & 1.4572 & 5.4 & 0.8373 & 1.4610 \\
\hline 86 & 6.0 & 0.8218 & 1.4506 & 5.2 & 0.8276 & 1.4550 & 5.0 & 0.8341 & 1.4585 \\
\hline " 85 & 3.4 & 0.8210 & 1.4491 & 2.2 & 0.8273 & 1.4530 & 3.0 & 0.8330 & 1.4559 \\
\hline
\end{tabular}




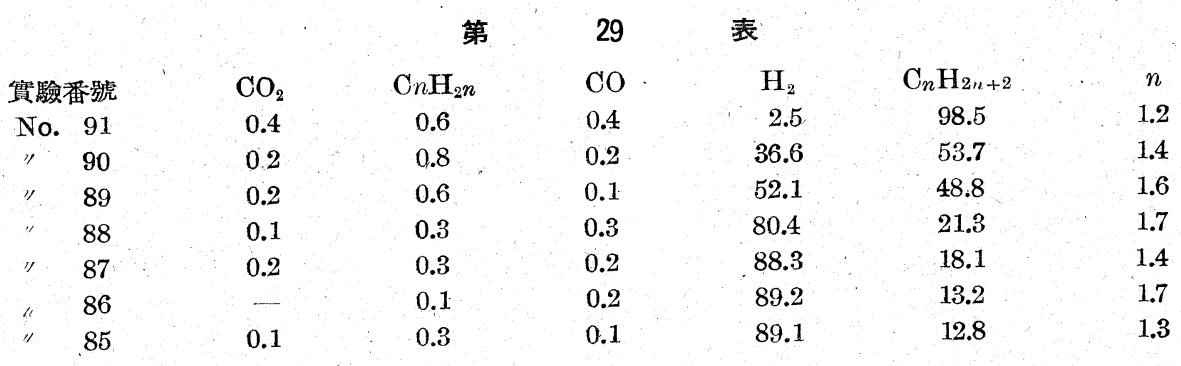

(ii) 水素純度の影響

使用水素に窒素を混じて水素の純度を種々に變じ其の初厭, 處理溫度, 處理時間, 觸媒の添 加量等一定條件の下に各種純度の水素の處理油の性狀に及ぼす影響につを檢した。其の結果は 第 30〜34 表に示せる如くである。師ち水素の消費量は水素の純度の低下と共に減少し，最高 及び最低壓力は增加す。水素純度の低下に依る $\mathrm{P}_{0}$ 曲線の變化は No. 97 亿於て汢(窒素のみ) 厭力の降下を示さず處理時間の經過と共飞增加するのみである。水素純度 $51.3 \%$ 以上に於け る $\mathrm{P}_{0}$ 曲線の傾斜度は水素純度の增加と共に大となる。處理油は純度の低下と共に黃紅色より 綠色を帶ぶるに至り逐に暗褐色となる。包收率法漸減し比重輕質油分を增加するに拘らず漸增： す。含有パラフィン蠟の量屿純度の低下と共飞分解進み漸减す。處理油の各溜分に於ける $90 \%$ $\mathrm{H}_{2} \mathrm{SO}_{4}$ 飞よる損失\%沈純度の低下と共飞增加し， $d_{4^{\circ}}^{250}, n_{D}^{25^{\circ}}$ は增加の傾向にある。以上の如く 水素純度の低下の處理油の饱和度に及ばす影響は $200^{\circ} \mathrm{C}$ 以下の溜分より\& $200^{\circ} \mathrm{C}$ 以上の溜分 に於て著しく，水素の純度は $87.0 \%$ のものてても相當飽和せしめ得らるつ事を知つた。

第 30 表（觸媒 $\mathrm{Ni}-\mathrm{Mo}-\mathrm{S}$-白土 $10 \%$ ）

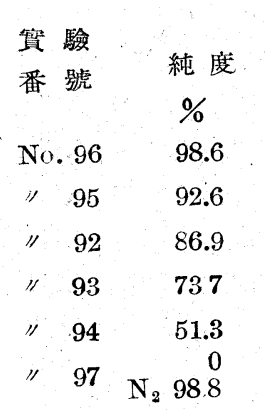

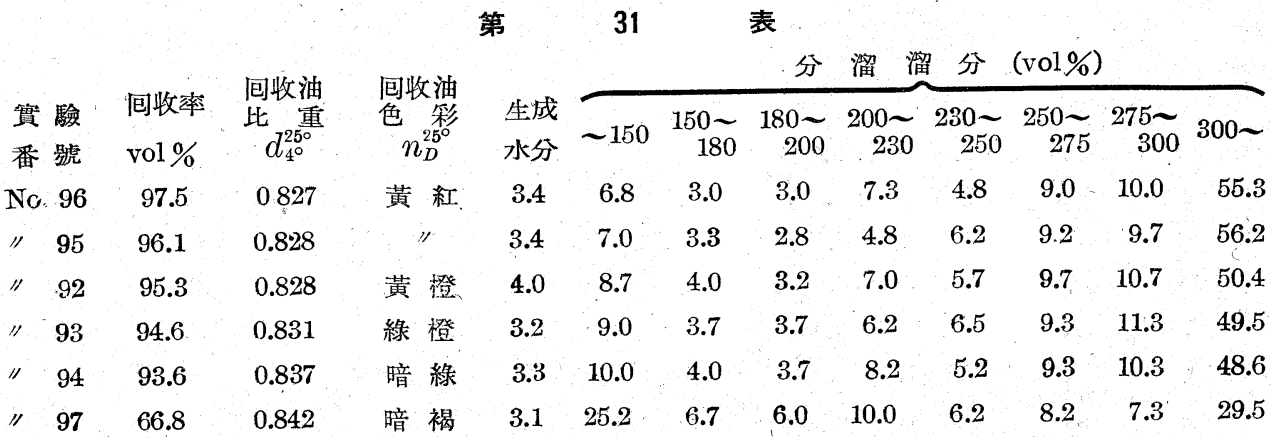


貫驗番號

No. 96

" 95

") 92

" 93

" 94

1/ 97

第 32 婊

$300^{\circ} \mathrm{C}$ 以上溜分パラフィン蠟

$\begin{array}{cr}\text { 含有量 } \mathrm{g} \% & \text { M. P. }{ }^{\circ} \mathrm{F} \\ 31.3 & 125.8 \\ 28.4 & 123.6 \\ 27.9 & 124.1 \\ 24.1 & 123.8 \\ 23.6 & 122.4\end{array}$

第 33 表 (1)
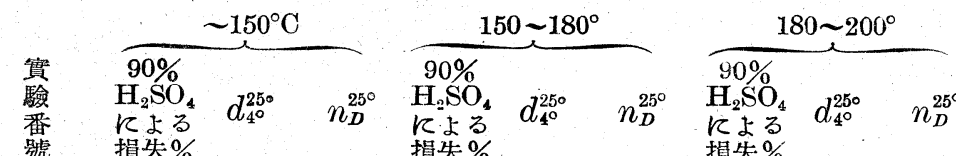

$\overbrace{90 \%}^{200 \sim 230^{\circ}}$

$\underset{\text { Kよる }}{\mathrm{H}_{2} \mathrm{SO}_{4}} d_{4^{\circ}}^{25^{\circ}} \quad n_{D}^{25^{\circ}}$

$\begin{array}{lll}\mathrm{H}_{2} \mathrm{SO}_{4} & d_{4^{\circ}}^{25 \circ} & n_{D}^{25^{\circ}}\end{array}$

$\mathrm{H}_{2} \mathrm{SO}_{4} \quad d_{4^{\circ}}^{25 \circ} \quad \dot{n}_{D}^{25^{\circ}}$ 損失\%

損失\%

$\begin{array}{lllllllllllll}\text { No. } 96 & 4.5 & 0.7170 & 1.3930 & 5.6 & 0.7799 & 1.4272 & 7.4 & 0.8009 & 1.4385 & 7.2 & 0.8229 & 1.4511\end{array}$

損失\%

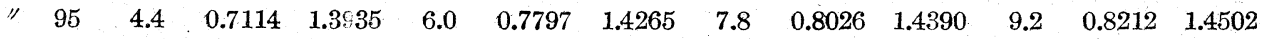

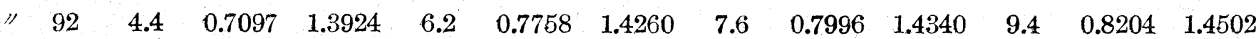

" $\quad \begin{array}{lllllllllllll}93 & 6.6 & 0.7103 & 1.3931 & 8.8 & 0.7747 & 1.4270 & 12.8 & 0.8049 & 1.4429 & 14.4 & 0.8260 & 1.4533\end{array}$

$\begin{array}{lllllllllllll}94 & 7.4 & 0.7003 & 1.3910 & 10.0 & 0.7797 & 1.4278 & 14.4 & 0.8094 & 1.4439 & 16.6 & 0.8315 & 1.4561\end{array}$

$\begin{array}{llllllllllllll}\text { "/ } & 97 & 17.4 & 0.7050 & 1.3942 & 13.2 & 0.7911 & 1.4320 & 15.6 & 0.8134 & 1.4432 & 18.6 & 0.8378 & 1.4569\end{array}$

\begin{tabular}{|c|c|c|c|c|c|c|c|c|c|}
\hline & & $30 \sim 250^{\circ}$ & & $\begin{array}{r}\text { 上 } \\
250\end{array}$ & $\begin{array}{r}\text { 上 }(2) \\
0 \sim 275^{\circ}\end{array}$ & & 275 & $\sim 300^{\circ}$ & \\
\hline & $\begin{array}{c}90 \% \mathrm{H}_{2} \mathrm{SO}_{4} \mathrm{~K} \\
\text { よる損失\% }\end{array}$ & $d_{4^{\circ}}^{25 \circ}$ & $n_{D}^{25^{\circ}}$ & $\begin{array}{l}90 \% \mathrm{H}_{2} \mathrm{SO}_{4} \mathrm{~K} \\
\text { よる損失\% }\end{array}$ & $d_{4^{\circ}}^{25 \circ}$ & $n_{D}^{25^{\circ}}$ & $\begin{array}{l}90 \% \mathrm{H}_{2} \mathrm{SO}_{4} \mathrm{~K} \\
\text { よる損失\% }\end{array}$ & $d_{4^{\circ}}^{25 \circ}$ & 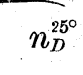 \\
\hline o. 96 & 7.2 & 0.8323 & 1.4570 & 8.4 & 0.8374 & 1.4604 & 8.4 & 0.8427 & 1.4649 \\
\hline 95 & 10.0 & 0.8332 & 1.4568 & 9.4 & 0.8413 & 1.4922 & 9.2 & 0.8466 & 1.4660 \\
\hline 92 & 11.2 & 0.8314 & 1.4572 & 11.8 & 0.8397 & 1.4620 & 11.2 & 0.8481 & 1.4661 \\
\hline 93 & 14.8 & 0.8382 & 1.4610 & 15.6 & 0.8464 & 1.4666 & 15.8 & 0.8561 & 1.4720 \\
\hline 94 & 16.6 & 0.8410 & 1.4630 & 16.6 & 0.8505 & 1.4641 & 18.4 & 0.85 .2 & 1.4746 \\
\hline 97 & 19.2 & 0.8591 & 1.4700 & 22.0 & 0.8757 & 1.4819 & $24: 4$ & 0.8951 & 1.4958 \\
\hline
\end{tabular}

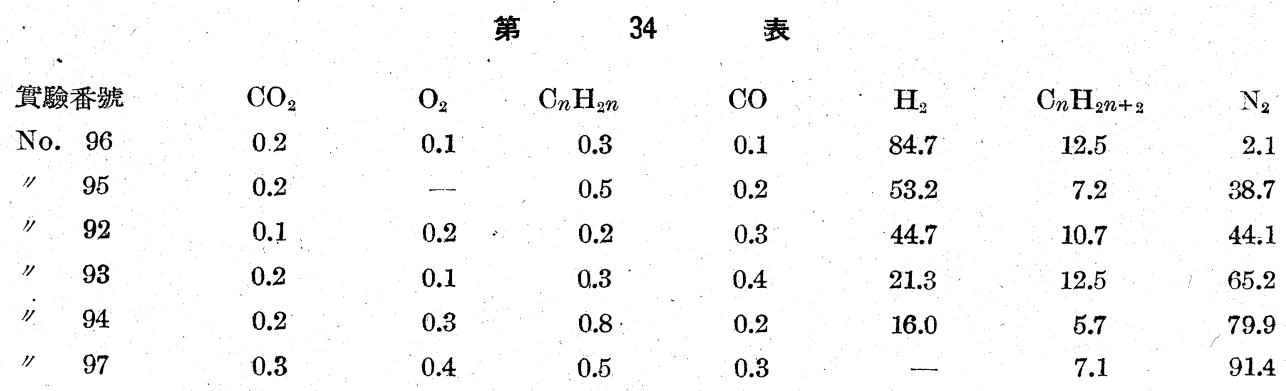




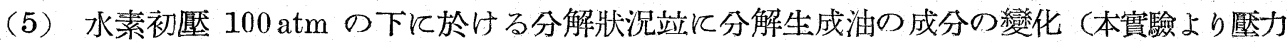
計は $\mathrm{kg} / \mathrm{cm}^{2}$ 單位のるのを使用せるため壓力は $\mathrm{kg} / \mathrm{cm}^{2}$ にて表はした）

（i）無觸媒，反應溫度の影響

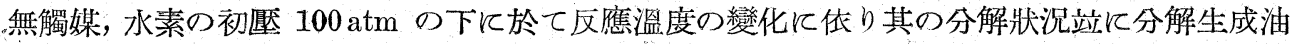
の成分の變化を檢せんがをめに行へるものにして, 反應溫度を $400 〜 480^{\circ} \mathrm{C}$ 迄 $20^{\circ} \mathrm{C}$. 宛變化し， 各溫度飞 60 分間保つた。其の結果第 35〜40 表に示せる如くである。郎ち水素の消費量立 そ生成ガス中のガス狀炭化水素は溫度の上昇之共飞增加し, 各反應溫度に於ける $\mathrm{P}_{0}$ 曲線怕何 れの場合子實驗開始後 15 分郎ち $50 \sim 60^{\circ} \mathrm{C}$ 亿達する迄は上昇し, 此の溫度に於て最高を示し 60 分後郎ち $330 \sim 340^{\circ} \mathrm{C}$ 亿達する迄牥右方に傾斜しそれ以後は殆ど一直線をなす。更と $\mathrm{P}_{0}$ 曲 線汢 $50 \sim 60^{\circ} \mathrm{C}$ の點を最高として右方に 傾斜し始むる事より此の溫度に於て油中に 水素の溶 解或吐吸收反應が開始せらる〉ものと思考される。加熱速度の變化江水素の吸收或は分解反 應に著しき影響を與ふるものなるが故に可及的同一速度にて加熱する樣努めた。冷却時に於け る $\mathrm{P}_{0}$ 曲線は $440^{\circ} \mathrm{C}$ とては殆ど一直線をなすが，此の溫度を限界としてそれ以下の溫度て於て 汢右方に上昇しそれ以上の溫度飞於ては反對に下向する傾向を示す。生成油汢濾過したる後其 の包收率及び比重を測定し一定量を採り Hewpel 裝置に依り分溜した。各溜分の $d_{4^{\circ}}^{25 \circ} 225^{\circ} \mathrm{C}$ 以下の溜分に於ては反應溫度の上显と共に減少するも，それ以上の溜分に於ては重合反應を伴 ふ結果增加し，No. 5 亿於ては各溜分共著しく增加した。各溜分の成分を一般的方法に依り測 定せる結果汢第 38 表に示せる如くである。反應溫度の變化に依る分解汇既に 前述せる如く $440^{\circ} \mathrm{C}$ 以上の溫度に於ては著しく旺盛となるが故に，今 $450^{\circ} \mathrm{C}$ を界とし第 38 表について其の

\section{第 35 表 反礁條件竝に結果}

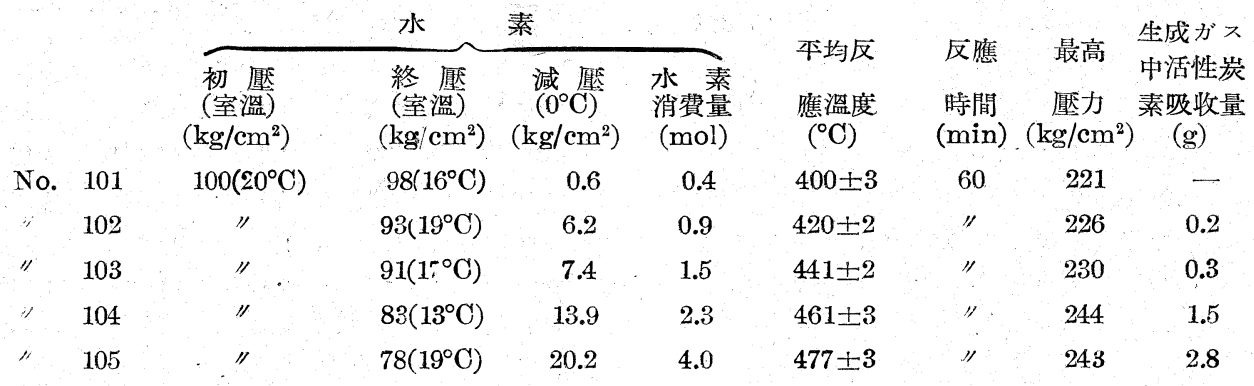

第 36 表生成 油性 狀（vol\%）

\begin{tabular}{|c|c|c|c|c|c|c|c|c|c|c|c|}
\hline & & & & & & 各 & 留 & 收 & & & \\
\hline & $\begin{array}{c}\text { 反應溫廘 } \\
\left({ }^{\circ} \mathrm{C}\right)\end{array}$ & $\begin{array}{l}\text { 回收率 } \\
\text { (vol\%) }\end{array}$ & 比重 & $\sim 100$ & $\begin{array}{r}100 \sim \\
150\end{array}$ & ${ }_{175}^{150 \sim}$ & $\begin{array}{r}175 \sim \\
200\end{array}$ & $200 \sim$ & $\begin{array}{r}225 \sim \\
250\end{array}$ & $\begin{array}{r}250 \sim \\
275\end{array}$ & $\begin{array}{r}275-1 \\
300\end{array}$ \\
\hline 101 & $400 \pm 3$ & 97.0 & $0.886\left(40^{\circ} \mathrm{C}\right)$ & 0.2 & 0.4 & 0.7 & 1.2 & 3.5 & 5.3 & 7.0 & 9.5 \\
\hline 102 & $420 \pm 2$ & 95.0 & $0.882(")$ & 1.2 & 1.2 & 1.2 & 1.9 & 3.9 & 5.1 & 8.3 & 8.8 \\
\hline 103 & $441 \pm 2$ & 94.0 & $0.875\left(25^{\circ} \mathrm{C}\right)$ & 4.9 & 4.7 & 3.3 & 4.0 & 5.7 & 7.5 & 6.6 & 8.3 \\
\hline 104 & $461 \pm 3$ & 88.0 & $0.852(")$ & 10.8 & 9.9 & 5.0 & 5.1 & 7.4 & 6.7 & 8.1 & 7.4 \\
\hline 105 & $477 \pm 3$ & 70.0 & $0.846(")$ ) & 234 & 16.9 & 7.1 & 7.4 & 6.9 & 5.7 & 6.7 & 4.3 \\
\hline
\end{tabular}


第 37 表各溜分の比重及び屈折率

\begin{tabular}{|c|c|c|c|c|c|c|c|c|c|}
\hline 溜分 & & $\sim 100$ & $100 \sim 150$ & $150 \sim 175$ & $175 \sim 200$ & $200 \sim 225$ & $225 \sim 250$ & $250 \sim 275$ & $275 \sim 30$ \\
\hline (.No. & 101 & . & & 0.7980 & & 0.8260 & 0.8412 & 0.8530 & 0.8640 \\
\hline " & 102 & & & 0.7740 & & 0.8320 & 0.8439 & 0.8550 & 0.8630 \\
\hline$\%$ & 103 & 0.6719 & 0.7342 & 0.7723 & 0.7979 & 0.8226 & 0.8420 & 0.8539 & 0.8670 \\
\hline " & 104 & 0,6608 & 0.7282 & 0.7680 & 0.7961 & 0.8222 & 0.8430 & 0.8620 & 0.8807 \\
\hline " & 105 & 0.6645 & 0.7385 & 0.7861 & 0.8241 & 0.8610 & 0.8959 & 0.9300 & 0.9747 \\
\hline$"$ & 101 & & & 1.4449 & & 1.4617 & 1.4700 & 1.4775 & 1.4840 \\
\hline$"$ & 102 & & & 1.4271 & & 1.4571 & 1.4672 & 1.4754 & 1.4823 \\
\hline " & 103 & 1.3819 & 1.4132 & 1.4305 & 1.4448 & 1.4589 & 1.4697 & 1.4780 & 1.4848 \\
\hline " & 104 & 1.3785 & 1.4095 & 1.4300 & 1.4500 & 1.4595 & 1.4745 & 1.4845 & 1.4950 \\
\hline " & 105 & 1.3817 & 1.4155 & 1.4405 & 1.4596 & 1.4819 & 1.5032 & 1.5264 & 1.5502 \\
\hline
\end{tabular}

$\left({ }^{\circ} \mathrm{C}\right)$ $\sim 100\left\{\begin{array}{l}\text { 不飽和 炭化水素 } \\ \text { 芳香族炭化水素 } \\ \text { ナフテン族炭化水素 } \\ \text { パシフィン族炭化水素 }\end{array}\right.$ $100 \sim 150\left\{\begin{array}{l}\text { 不飽和炭化水素 } \\ \text { 芳香族炭化水素 } \\ \text { ナフテン族炭化水素 } \\ \text { パラフィン族炭化水素 }\end{array}\right.$ $150 \sim 175\left\{\begin{array}{l}\text { 不飽和 炭化 水素 } \\ \text { 芳香 族 炭化水素 } \\ \text { ナフテン族炭化水素 } \\ \text { パラフィン族炭化水素 }\end{array}\right.$

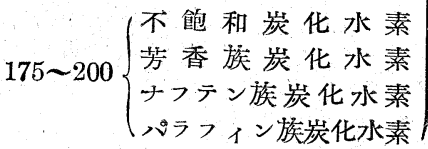
$200 \sim 225\left\{\begin{array}{l}\text { 不飽 和 炭化水素 } \\ \text { 芳香 族 炭化水素 } \\ \text { ナフテン族炭化水素 } \\ \text { パラフィン族炭化水素 }\end{array}\right.$ 225 250 $\left\{\begin{array}{l}\text { 不飽 和炭化水素 } \\ \text { 秀 族炭化水素 } \\ \text { ナフテン族炭化水素 } \\ \text { パラフィン族炭化水素 }\end{array}\right.$ $250 \sim 275\left\{\begin{array}{l}\text { 不飽, 和炭化水素 } \\ \text { 芳香族炭化水素 } \\ \text { ナフテン族炭化水素 } \\ \text { ペラフィン族炭化水素 }\end{array}\right.$ 275 300 $\left\{\begin{array}{l}\text { 不飽和炭化水素 } \\ \text { 芳香族炭化水素 } \\ \text { ナフテン族炭化水素 } \\ \text { パラフィン族炭化水素 }\end{array}\right.$
No. 101

No. 102

\section{No.}

22.8

2.4

6.7

64.1

8.8

12.0

5.0

74.2

13.0

23.6

4.8

58.6

15.8

18.6

2.8

62.8

9.2

16.2

7.3

67.3

10.6

20.0

3.8

65.6

14.6

25.6

4.1

55.5

15.0

25.8

4.0

55.2

16.2

25.2

4.0

54.6

18.8

24.2

3.1

53.9
No. 104

12.2

1.0

5.7

81.1

6.0

29.0

3.3

51.7

7.2

15.8

5.9

71.1

11.4

17.4

3.0

68.2

14.2

17.9

4.4

63.5

13.8

22.2

1.4

62.6

15.8

23.2 .

1.8

59.2

19.4

22.8

1.7

56.1
No. 105

7.6

4.8

7.1

80.5

5.6

23.6

5.1

65.7

7.4

20.8

5.5

66.3

12.0

25.6

3.2

59.2

15.8

19.6

5.2

59.4

19.2

17.4

5.4

58.0

26.2

39.8

2.9

31.1

34.0

42.0

1.1 22.9 
成分の變化を見るに，第 39 表に總括せ る如く $450^{\circ} \mathrm{C}$ 以下の反應溫度飞於て江 $200^{\circ} \mathrm{C}$ 以下の溜分には主として不飽和炭 化水素多く， $200^{\circ} \mathrm{C}$ 以上の溜分飞は主 として芳香族及びナフテン族炭化水素 が多い。 $450^{\circ} \mathrm{C}$ 以上の反應溫度に於て沖 $200^{\circ} \mathrm{C}$ 以下の溜分飞汢芳香族炭化水素多 < $200^{\circ} \mathrm{C}$ 以上の溜分飞は不飽和炭化水素 が多い。此の事實より $450^{\circ} \mathrm{C}$ 以上の反 應溫度に於ては原油の主として $300^{\circ} \mathrm{C}$ 以 上の溜分が分解せられ不飽和炭化水素を 多量に生成し，其の一部は環狀化して芳 香族炭化水素を生成し, 各溜分中に多量 飞存在すると共飞他の部分汢重合して主 として $200^{\circ} \mathrm{C}$ 以上の溜分中に存在するも のと考へられる。乙れ飞反し $450^{\circ} \mathrm{C}$ 以下 の反應溫度飞於て汒 $300^{\circ} \mathrm{C}$ 以上の溜分の 分解不充分にして且つ分解に依て生成せ る不飽和炭化水素江環狀化を行ふに至ら ず，其のま 主として $200^{\circ} \mathrm{C}$ 以下の溜分

\section{第 39 表 各溜分の成分比較}

\begin{tabular}{|c|c|c|c|c|c|}
\hline 溜分 $\left({ }^{\circ} \mathrm{C}\right)$ & 反應溫度 $450^{\circ} \mathrm{C}$ & 以下 & $450^{\circ} \mathrm{C}$ & & \\
\hline$\sim 100$ & 不 飽 和 & 多 & $\left\{\begin{array}{l}\text { 芳 香 } \\
\text { パラフィ } \\
ナ フ \text { テ }\end{array}\right.$ & & $\begin{array}{l}\text { 多 } \\
\text { 多 }\end{array}$ \\
\hline $00 \sim 150$ & $\begin{array}{l}\text { 不飽 和 } \\
\text { パラフィン }\end{array}$ & 多\} & 芳 香 & 娭 & \\
\hline $50 \sim 175$ & $\begin{array}{l}\text { 不飽 和 } \\
\text { ナフテン }\end{array}$ & 多 & $\begin{array}{l}\text { 芳香 } \\
\text { パラフィ }\end{array}$ & & \\
\hline $75 \sim 200$ & ナフテン & 多 & $\begin{cases}\text { 不 } & \text { 飽 } \\
\text { 芳 } & \text { 香 }\end{cases}$ & & \\
\hline $00 \sim 225$ & $\begin{array}{l}\text { 芳香 族 } \\
\text { 侯 }\end{array}$ & 多 & $\begin{array}{l}\text { 不 飽 } \\
\text { ナテテ }\end{array}$ & & \\
\hline $25 \sim 250$ & 芳 香 族 & 多 & $\left\{\begin{array}{l}\text { 不 飽 } \\
ナ フ テ\end{array}\right.$ & & \\
\hline $250 \sim 275$ & ナフテン & 多 & $\begin{cases}\text { 不 } & \text { 飽 } \\
\text { 芳 } & \text { 香 }\end{cases}$ & & \\
\hline $75 \sim 300$ & $\begin{array}{l}\text { ナフテン } \\
\text { パラフィン }\end{array}$ & $\begin{array}{l}\text { 多 } \\
\text { 多 }\end{array}$ & $\begin{array}{l}\text { 不 飽 } \\
\text { 芳 香 }\end{array}$ & & \\
\hline
\end{tabular}

\section{第 40 表生成ガ ス成分}

$\begin{array}{lllllll}\mathrm{CO}_{2} & \mathrm{O}_{2} & \mathrm{C}_{n} \mathrm{H}_{2} n & \mathrm{CO} & \mathrm{H}_{2} & \mathrm{C}_{n} \mathrm{H}_{2 n+2}\end{array}$

\begin{tabular}{|c|c|c|c|c|c|}
\hline No. 101 & 0.7 & 0.3 & 0.3 & 0.2 & 92.5 \\
\hline 102 & 0.6 & 0.3 & 0.0 & 0.6 & 91.9 \\
\hline " 103 & 0.5 & 0.0 & 0.3 & 0.3 & 85.9 \\
\hline " 104 & 0.3 & 0.3 & 0.4 & 0.6 & 82.6 \\
\hline 105 & 0.3 & 0.1 & 0.5 & 0.5 & 65.1 \\
\hline
\end{tabular}
飞殘存するものと考へられる。反應溫度 $450^{\circ} \mathrm{C}$ 以下の場合 $200^{\circ} \mathrm{C}$ 以上の溜分中に比較的ナフ テン多く, $450^{\circ} \mathrm{C}$. 以上の溫度に於ては同一溜分中に芳香族比較的多を事實は $450^{\circ} \mathrm{C}$ を界として 芳香族せナフテン族の反應も同時に起るものと想像される。生成ガス中の $\mathrm{C}_{n} \mathrm{H}_{2 n+2}$ の量は 反應溫度の上昇と共に增加し， $440^{\circ} \mathrm{C}$ にて $12.7 \%$ なるに $480^{\circ} \mathrm{C}$ とは急激に增加して 44.6 \%を示した。

(ii）觸媒の種類の影響

Mo 系觸媒の優秀なる事は既に認めた。本實驗に於て沈， $\mathrm{Mo}$ 系觸媒として $\mathrm{MoO}_{3},\left(\mathrm{NH}_{4}\right)_{2}$ $\mathrm{MoO}_{4},\left(\mathrm{NH}_{4}\right)_{2} \mathrm{MoS}_{4}, \mathrm{Ni}-\mathrm{Mo}$-S-白土の 4 種を使用した。. 前 3 者㳉何れもメルク製市販品, NiMo-S-白土汢前記の方法飞依り調製せるものである。水素初壓 $100 \operatorname{atm}\left(20^{\circ} \mathrm{C}\right)$, 反應溫度 $460^{\circ} \mathrm{C}$, 60 分間保持せる場合の分解狀況端に生成油成分の變化を檢した。實驗結果沬第 $41 〜 45$ 表に示 せる如くである。即ち同一反應溫度に於て水素の消費量は Ni-Mo-S-白土最も大にして 7.2 $\mathrm{mol}$ を示し， $\mathrm{MoO}_{3}$ 最も小として $5.1 \mathrm{~mol}$ を示したが，之を同一反應溫度に於て觸媒を使用せ ざるNo.4の $2.3 \mathrm{~mol}$ と比すれば著しく大である。各實驗に於ける $\mathrm{P}_{0}$ 曲線は實驗開始後 10 〜15 分にして最高に達し, 此の溫度を反應開始溫度とすれば各實驗共 $40 \sim 60^{\circ} \mathrm{C}$ を示し, No. 4 と殆ぞ同樣である。此の點以後 $\mathrm{P}_{0}$ 曲線は右方に傾斜し, No. 4 に於ては $330^{\circ} \mathrm{C}$ 附近より一 


\section{第 41 表 及鹰條件站 22 結果}

\begin{tabular}{|c|c|c|c|c|c|c|c|c|c|}
\hline & 觸 & $\begin{array}{c}\text { 初 䣌 } \\
\text { (窒溫) } \\
\left(\mathrm{kg} / \mathrm{cm}^{2}\right)\end{array}$ & $\begin{array}{c}\text { 終 厴 } \\
\text { (室溫) } \\
\left(\mathrm{kg} / \mathrm{cm}^{2}\right)\end{array}$ & $\begin{array}{c}\text { 減 }\left(0^{\circ} \mathrm{C}\right) \\
\left(\mathrm{kg} / \mathrm{cm}^{2}\right)\end{array}$ & $\begin{array}{l}\text { 水 素 } \\
\text { 消費量 } \\
\text { (mol) }\end{array}$ & $\begin{array}{c}\text { 本均反 } \\
\text { 應盜度 } \\
\left({ }^{\circ} \mathrm{C}\right)\end{array}$ & $\begin{array}{l}\text { 反應 } \\
\text { 時間. } \\
\text { (min) }\end{array}$ & $\begin{array}{c}\text { 最高 生 } \\
\text { 埾力 吸 } \\
\left(\mathrm{kg} / \mathrm{cm}^{2}\right)\end{array}$ & $\begin{array}{l}\text { 生成ガ } \\
\text { 中活性炭 } \\
\text { 吸收量 } \\
)^{(\mathrm{g})}\end{array}$ \\
\hline อ. 106 & $\mathrm{MoO}_{3}$ & $100\left(20^{\circ}\right)$ & $51\left(12^{\circ}\right)$ & 44.4 & 5.1 & $460 \pm 2$ & 60 & 201 & 1.0 \\
\hline 107 & $\left(\mathrm{NH}_{4}\right)_{2} \mathrm{MoO}_{4}$ & " & $48\left(15^{\circ}\right)$ & 47.2 & 6.5 & $461 \pm 2$ & " & 205 & 1.1 \\
\hline 108 & $\left(\mathrm{NH}_{4}\right)_{2} \mathrm{MoS}_{4}$ & " & $46\left(16^{\circ}\right)$ & 49.8 & 6.7 & $461 \pm 2$ & " & 200 & 0.9 \\
\hline 109 & Ni-Mo-S-白土 & " & $37\left(12^{\circ}\right)$ & 57.7 & 7.2 & $461 \pm 3$ & "I & 190 & 1.0 \\
\hline
\end{tabular}

\section{第 42 表生成 油 性 狀}

\begin{tabular}{|c|c|c|c|c|c|c|c|c|c|c|c|}
\hline & 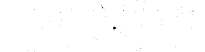 & & & & & 溜 & 分 & $\left({ }^{\circ} \mathrm{C}\right)$ & & & \\
\hline & 媒 & $\begin{array}{l}\text { 包收率 } \\
\text { (vol\%) }\end{array}$ & $\stackrel{\text { 比 重 }}{\left(25^{\circ} \mathrm{C}\right)}$ & $\sim 100$ & $100 \sim$ & $\begin{array}{r}150 \sim \\
175\end{array}$ & $\begin{array}{r}175 \sim \\
200\end{array}$ & $200 \sim$ & $\begin{array}{r}225 \sim \\
250\end{array}$ & $\begin{array}{r}250 \sim \\
275\end{array}$ & $\begin{array}{r}275 \sim \\
300\end{array}$ \\
\hline o. 106 & $\mathrm{MoO}_{3}$ & 90.5 & 0.833 & 7.0 & 7.0 & 3.6 & 4.7 & 5.6 & 8.3 & 7.6 & 10.1 \\
\hline 107 & $\left(\mathrm{NH}_{4}\right)_{2} \mathrm{MoO}_{4}$ & 91.3 & 0.832 & 8.2 & 8.6 & 5.0 & 4.5 & 6.5 & 8.3 & 8.1 & 8.9 \\
\hline 108 & $\left(\mathrm{NH}_{4}\right)_{2} \mathrm{MoS}_{4}$ & 93.7 & 0.823 & 7.0 & 7.1 & 5.3 & 7.1 & 7.1 & 9.9 & 7.6 & 9.2 \\
\hline 109 & Ni-Mo-S-白土 & 97.2 & 0.808 & 11.8 & 13.6 & 7.0 & 67 & 9.1 & 9.7 & 6.4 & 7.5 \\
\hline
\end{tabular}

\section{第 43 表各溜分の比重及 び屈折率}

\begin{tabular}{|c|c|c|c|c|c|c|c|c|c|}
\hline & 分 $\left({ }^{\circ} \mathrm{C}\right)$ & -100 & $100 \sim 150$ & $150 \sim 175$ & $175 \sim 200$ & $200 \sim 225$ & $225 \sim 250$ & $250 \sim 275$ & $275 \sim 300$ \\
\hline & .106 & 0.6635 & 0.7318 & 0.7759 & 0.7975 & 0.8209 & 0.8374 & 0.8484 & 0.8608 \\
\hline & 107 & 0.6772 & 0.7292 & 0.7669 & 0.7954 & 0.8177 & 0.8322 & 0.8471 & 0.8573 \\
\hline & 108 & 0.6617 & 0.7321 & 0.7702 & 0.7965 & 0.8198 & 0.8375 & 0.8488 & 0.8606 \\
\hline & 109 & 0.6678 & 0.7349 & 0.7724 & 0.8002 & 0.8186 & 0.8369 & 0.8455 & 0.8578 \\
\hline & 106 & 1.3816 & 1.4111 & 1.4335 & 1.4460 & 1.4591 & 1.4680 & 1.4768 & 1.4843 \\
\hline & 107 & 1.3864 & 1.4109 & 1.4317 & 1.4457 & 1.4575 & 1.4632 & 1.4755 & 1.4828 \\
\hline & 108 & 1.3822 & 1.4128 & 1.4327 & 1.4468 & 1.4590 & 1.4690 & 1.4767 & 1.4843 \\
\hline & 109 & 1.2879 & 1.4131 & 1.4340 & 1.4485 & 1.4594 & 1.4705 & 1.4771 & 1.4850 \\
\hline
\end{tabular}

第 44 表各溜分 $の$ 成 分 (vol\%)

\begin{tabular}{|c|c|c|c|c|c|}
\hline \multicolumn{2}{|l|}{ 溜分 $\left({ }^{\circ} \mathrm{C}\right)$} & No. 106 & No. 107 & No. 108 & No. 109 \\
\hline \multirow{4}{*}{$\sim 100$} & 不飽 和炭化水素 & 4.8 & 4.0 & 5.6 . & 3.0 \\
\hline & 芳香族炭化水素 & 8.0 & 8.2 & 7.6 & 16.2 \\
\hline & ナフテン族炭化水素 & 4.1 & 5.0 . & 4.8 & 3.1 \\
\hline & パラフィン族炭化水素 & 83.1 & 82.8 & 82.0 & 77.7 \\
\hline \multirow{4}{*}{$100 \sim 150$} & 不飽和炭化水素 & 4.0 & 2.8 & 3.6 & 1.6 \\
\hline & 芳香族炭化水素 & 9.6 & 10.4 & 9.6 & 12.0 \\
\hline & ナフテン族炭化水素 & 1.8 & 1.8 & 1.8 & 1.8 \\
\hline & パラフィン族炭化水素 & 84.6 & 85.0 & 85.0 & 84.6 \\
\hline \multirow{4}{*}{$150 \sim 175$} & 不飽和炭化水素 & 5.0 & 4.6 & 4.8 & 2.8 \\
\hline & 芳香族炭化水素 & 15.2 & 15.8 & 19.4 & 17.2 \\
\hline & ナフテン族炭化水素 & 2.7 & 2.7 & 2.2 & 5.7 \\
\hline & パラフィン族炭化水素 & 77.1 & 76.9 & 73.6 & 74.3 \\
\hline
\end{tabular}




\begin{tabular}{|c|c|c|c|c|c|}
\hline \multicolumn{2}{|l|}{ 溜分 $\left({ }^{\circ} \mathrm{C}\right)$} & No. 106 & No. 107 & No. 108 & No. 109 \\
\hline \multirow{4}{*}{$175 \sim 200$} & 不 館 和“炭 化 水 素 & 8.6 & 5.4 & 5.0 & 2.2 \\
\hline & 芳香族炭代水素 & 16.6 & 19.0 & 20.8 & 21.8 \\
\hline & ナフテン族炭化水素 & 4.1 & 4.2 & 4.7 & 6.5 \\
\hline & パラフィン族炭化水素 & 70.7 & 71.4 & 69.5 & 69.5 \\
\hline \multirow{4}{*}{$200-225$} & 不 飽 和 炭 化 水素 & 10.8 & 8.4 & 7.8 & 4.2 \\
\hline & 芳香族炭化水素 & 19.2 & 20.2 & 22.2 & 24.6 \\
\hline & ナフテン族炭化水素 & 5.4 & 5.5 & 5.1 & 6.1 \\
\hline & パラフィン族炭化水素 & 64.6 & 65.9 & 64.9 & 65.7 \\
\hline \multirow{4}{*}{$225 \sim 250$} & (不飽和炭化 水素 & 12.0 & 9.6 & 8.1 & 5.4 \\
\hline & 芳香族炭化水素 & 20.8 & 20.2 & $24: 5$ & 25.0 \\
\hline & ナフテン族炭化水素 & 4.9 & 5.1 & 5.2 & 6.5 \\
\hline & パラフィン族炭化水素 & 62.3 & 65.1 & 62.2 & 73.1 \\
\hline \multirow{4}{*}{$250 \sim 275$} & (不飽和炭化水素 & 12.6 & 11.0 & 9.6 & 4.8 \\
\hline & 芳香族炭化水素 & 19.4 & 19.0 & 22.8 & 21.2 \\
\hline & ナフテン族炭化水素 & 5.2 & 5.3 & 5.2 & 8.5 \\
\hline & パラフィン族炭化水素 & 62.8 & 64.7 & 62.4 & 65.5 \\
\hline \multirow{4}{*}{$275 \sim 300$} & 不飽和炭化水素 & 14.0 & 13.4 & 11.2 & 5.8 \\
\hline & 芳香族炭化水素 & 19.8 & 18.0 & 21.8 & 22.2 \\
\hline & ナフテン族炭化水素 & 5.4 & 5.0 & 4.0 & 6.5 \\
\hline & パラフィン族炭化水素 & 60.8 & 63.6 & -63.0 & 64.5 \\
\hline
\end{tabular}

\section{第 45 表各 溜 分 $の$ 成 分 (vol\%)}

溜分 $\left({ }^{\circ} \mathrm{C}\right)$

No. 4

1) 109

芳 香族 $($ No. $4 \quad 6.7$

ナフテン族 $\left\{\begin{array}{lll}\text { No. } & 4 \\ 》 & 109 & 19\end{array}\right.$

$$
\sim 100 \quad 100
$$

10.8

9.9

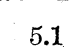

$00 \sim 2$

225

$\begin{array}{lll}11.8 & 13.6 & 7.0\end{array}$

32.3

13.8
21.7

22.9

$$
5.1
$$

6.7 .

9.1

20.4

22.3

28.3

30.1

315

$6.7 \quad 8.1 \quad 7.4$

$\begin{array}{lll}9.7 & 6.4 & 7.5\end{array}$

$23.6 \quad 25.0 \quad 24.5$

$\begin{array}{llll}31.5 & 29.7 & 28.7\end{array}$

第 46 表生成 ガ ス成 分 (vol\%)

$\begin{array}{cccccccc} & \mathrm{CO}_{2} & \mathrm{O}_{2} & \mathrm{C}_{n} \mathrm{H}_{2 n} & \mathrm{CO} & \mathrm{H}_{2} & . \mathrm{C}_{n} \mathrm{H}_{2 n+2} \\ \text { No. } 106 & 0.2 & 0.0 & 0.2 & 0.5 & 79.1 & 24.5 \\ \prime \prime & 107 & 0.1 & 0.2 & 0.3 & 0.4 & 74.1 & 26.9 \\ \prime \prime & 108 & 0.4 & 0.3 & 0.0 & 0.4 & 71.3 & 32.3 \\ \text { " } & 109 & 0.2 & 0.1 & 0.4 & 0.5 & 72.3 & 30.5\end{array}$

直線をなすも, 觸媒の存在する場合汢更に益々傾斜し, 冷却時に於ける $\mathrm{P}_{0}$ 曲線は觸媒を使用 せざるNo. 4 亿於て注右方に上昇する傾向を示すが，觸媒を使用する場合は反對に益々下向 する。反應生成油濾過したる後觸媒に附着せる油分をェーテルにて浸出间收し，全回收量及 
び比重を測定し，其の一定量を採り分溜した。郎ち $225^{\circ} \mathrm{C}$ 以下の溜分注 No. 106 , No. 107 , No. 108 共略々同樣なる值を示すが No. 109 亿於て注最も大，特に $175^{\circ} \mathrm{C}$ 以下の溜分に於て 著しい。225 $300^{\circ} \mathrm{C}$ 溜分に於ては各實驗共略々同一の值を示した。各溜分の $d_{4^{\circ}}^{25 \circ}, n_{D}^{25^{\circ}}$ 壮各 溜分共大なる變化をく略引同樣の值を示した。各溜分の成分の變化は No. 106 に於て 注各溜 分共不飽和炭化水素多量飞してNo. 109 亿於て㳉不飽和炭化水素最女少く, 各溜分共飞芳香族 名びナフテン族多量である。今同一反應溫度の下に於て觸媒を使用せる場合 (No. 109) を使用 せざる場合 (No.4) とを比較するに，第 45 表の如く各分溜溜分に於ては $\left(250\right.$ 2 $\left.25^{\circ}\right)$ 溜分を 除く外其の收量者增加し芳香族十ナフテン族の量 \& (100〜 $\left.150^{\circ}\right)$ 溜分を除く外, 各溜分共著し く增加す。毁ち分解溫度以上の溫度に於て分解せる場合觸媒を使用すれば生成油の輕質油分の 增加及び芳香族+ナフテン族の生成に著しを效果ある事を認め得る。生成ガスの成分注觸媒の 種類に依り $\mathrm{C}_{n} \mathrm{H}_{2 n+2}$ の生成量飞著しき變化あり, 郎ち分解反應汢同一反應溫度の下に於て子 觸媒の種類に依り其の分解樣式を異にする事を認め得る。以上頁岩粗油を水素初厗 $100 \mathrm{~atm} の$ 下に反應溫度 $400 \sim 480^{\circ} \mathrm{C}$ に於ける分解狀況竝に分解生成油の成分の變化を檢し, 分解反應 は $440^{\circ} \mathrm{C}$ を限界とし此の溫度以上飞於ては急激に旺盛となり, 又生成油の性狀より反應溫度 の上景と共飞重合反應子益々盛んとなる事を認め, 且つ生成油の成分て就て㳉反應溫度 $450^{\circ} \mathrm{C}$ を限界とし，乙れ以下の溫度に於ては $200^{\circ} \mathrm{C}$ 以下の溜分に注之して不飽和族多く $200^{\circ} \mathrm{C}$ 以 上の溜分には主として芳香族历びナフテン族多く, $450^{\circ} \mathrm{C}$ 以上の反應溫度に於ては $200^{\circ} \mathrm{C}$ 以下 の溜分に不飽和族多を事を認めた。 